\title{
Dual isotope evidence for sedimentary integration of plant wax biomarkers across an Andes-Amazon elevation transect
}

\author{
Sarah J. Feakins ${ }^{\mathrm{a} *}$, Mong Sin Wu ${ }^{\mathrm{a}}$, Camilo Ponton ${ }^{\mathrm{a}}$, Valier Galy ${ }^{\mathrm{b}}$, A. Joshua West ${ }^{\mathrm{a}}$ \\ ${ }^{a}$ Department of Earth Sciences, University of Southern California, Los Angeles, California, USA \\ ${ }^{\mathrm{b}}$ Department of Marine Chemistry and Geochemistry, Woods Hole Oceanographic Institution, Woods Hole, \\ Massachusetts, USA \\ "Corresponding author: feakins@,usc.edu (Feakins)
}

\section{Key Points:}

- Leaf wax biomarkers were studied in soils and rivers from the Andes to the Amazon.

- Elevation trend found in $\mathrm{C}$ and $\mathrm{H}$ isotopic compositions of plant wax in soils.

- Plant wax in river-suspended sediments approximated uniform spatial integration.

- Carbon isotopic composition of $n$-alkanes differentiated with depth in soil and river.

- Petrogenic inputs of $n$-alkanes discerned by CPI and dual isotopic analyses. 


\section{Abstract}

Tropical montane regions tend to have high rates of precipitation, biological production, erosion, and sediment export, which together move material off the landscape and toward sedimentary deposits downstream. Plant wax biomarkers can be used to investigate sourcing of organic matter and are often used as proxies to reconstruct past climate and environment in sedimentary deposits. To understand how plant waxes are sourced within a wet, tropical montane catchment, we measure the stable $\mathrm{C}$ and $\mathrm{H}$ isotope composition $\left(\delta^{13} \mathrm{C}\right.$ and $\left.\delta \mathrm{D}\right)$ of $n$-alkanes and $n$-alkanoic acids in soils along an elevation transect and from sediments within the Madre de Dios River network along the eastern flank of the Peruvian Andes, draining an area of 75,400 $\mathrm{km}^{2}$ and $6 \mathrm{~km}$ of elevation. Soils yield systematic trends in plant wax $\delta^{13} \mathrm{C}\left(+1.75\right.$ and $+1.31 \% \mathrm{~km}^{-1}$, for the $\mathrm{C}_{29}$ $n$-alkanes and $\mathrm{C}_{30} n$-alkanoic acids respectively in the mineral horizon) and $\delta \mathrm{D}$ values ( -10 and $12 \% \mathrm{~km}^{-1}$, respectively) across a $3.5 \mathrm{~km}$ elevation transect, which approximates trends previously reported from canopy leaves, though we find offsets between $\delta^{13} \mathrm{C}$ values in plants and soils. River suspended sediments generally follow soil isotopic gradients defined by catchment elevations $\left(\delta^{13} \mathrm{C}:+1.03\right.$ and $+0.99 \% \mathrm{~km}^{-1}$ and $\delta \mathrm{D}:-10$ to $-7 \% \mathrm{~km}^{-1}$, for the $\mathrm{C}_{29} n$ alkanes and $\mathrm{C}_{30} n$-alkanoic acids respectively) in the wet season, with a lowering in the dry season that is less well-constrained. In a few river suspended sediments, petrogenic contributions and depth-sorting influence the $n$-alkane $\delta^{13} \mathrm{C}$ signal. Our dual isotope, dual compound class and seasonal sampling approach reveals no Andean-dominance in plant wax export, and instead that the sourcing of plant waxes in this very wet, forested catchment approximates that expected for spatial integration of the upstream catchment, thus with a lowland dominance on areal basis, guiding paleoenvironmental reconstructions in tropical montane regions. The dual isotope approach provides cross-check on the altitudinal signals and can resolve ambiguity such as might 
be associated with vegetation change or aridity in paleoclimate records. Further, the altitude effect encoded within plant waxes presents a novel dual-isotope biomarker approach to paleoaltimetry. 


\section{Introduction}

The transport of organic carbon (OC) by large river systems is a crucial component of the Earth's carbon cycle. Rivers erode and transport plant, soil and rock-derived (petrogenic) OC across the landscape, and that which survives degradation may be deposited in sedimentary basins. Among the world's river systems, the Amazon River is the largest in terms of drainage area (6.4 million $\mathrm{km}^{2}$ ) and discharge $\left(200,000 \mathrm{~m}^{3} \mathrm{~s}^{-1}\right)$ (Meybeck and Ragu, 2012), and its export of particulate organic carbon (POC; c. $11.6 \mathrm{Tg} \mathrm{yr}^{-1}$ to the Atlantic) represents $c .6 \%$ of the global riverine POC input to the oceans (Beusen et al., 2005; Galy et al., 2015; Richey et al., 1990). Understanding the sourcing, degradation, and transport of POC in the Amazon fluvial system is thus significant in budgeting the global carbon cycle, and has been extensively studied in both the lowland mainstreams and Andean head waters (e.g., Bouchez et al., 2014; Clark et al., 2013; Hedges et al., 2000; Townsend-Small et al., 2005; Townsend-Small et al., 2008). The Andes Mountains represent just $11 \%$ of the Amazon River catchment area, but may account for $90 \%$ of rock-debris exported from the Amazon River to the Atlantic Ocean (Meade et al., 1985). While globally, biospheric OC export generally scales with sediment load (Galy et al., 2015), POC carried by the lowland Amazon River is thought to be dominantly sourced from lowland forests implying a near-complete degradation of Andean-derived POC in transit or swamping by more extensive lowland contributions (Mayorga et al., 2005). The biospheric OC represents carbon fixed from the atmosphere, and if it escapes oxidation in transit (Cole et al., 2007; Hedges and Oades, 1997) and is sequestered in ocean sediments for up to $10^{8} \mathrm{yrs}$, it represents a long-term sink of atmospheric $\mathrm{CO}_{2}$ (France-Lanord and Derry, 1997; Galy et al., 2007). In contrast, if biospheric carbon decomposes in soils (Koven et al., 2017) or in transit (Richey et al., 2002), $\mathrm{CO}_{2}$ is returned to the atmosphere relatively rapidly, on decade-century timescales, related to the age of 
carbon in soils (Trumbore, 1993) and in rivers (Clark et al., 2013; Townsend-Small et al., 2007). Sourcing and degradation processes within the catchment need to be understood to determine which regions contribute to marine repositories both for carbon budget and paleoclimate applications. Yet, many prior source-to-sink carbon cycle studies are based upon bulk POC, which is a complex mixture of components with diverse age, residence time, degradation potentials and geochemical signatures that can be difficult to tease apart (Mayorga et al., 2005).

Biological marker molecules, or biomarkers, not only derive from a specific class of organism but also carry signatures of environment. These biomarkers can be variously used to investigate sourcing and track molecules in transit, and they are often used as proxies to reconstruct past climate and environment, which is predicated on understanding sourcing. Biomarkers provide tracers for specific components of terrestrial OC cycling and thus provide a clearer view of sourcing and fluvial integration processes than bulk OC. For example, lignin (Aufdenkampe et al., 2007; Goñi et al., 2000), terpenoids (Giri et al., 2015; Medeiros et al., 2012) and plant wax biomarkers (Freymond et al., 2018; Galy et al., 2011; Häggi et al., 2016; Hemingway et al., 2016; Hoffmann et al., 2016; Tao et al., 2015) have been used in riverine systems to trace biogenic OC derived from vascular plant biomass. In addition, biomarkers for microbial activity have been used to trace bacterial and archaeal components of terrestrial biospheric OC production exported by rivers (Hanna et al., 2016; Hemingway et al., 2017; Kim et al., 2012; Wagner et al., 2014).

Plant wax hydrogen $\left(\delta \mathrm{D}_{\text {wax }}\right)$ and carbon isotope compositions $\left(\delta^{13} \mathrm{C}_{\mathrm{wax}}\right)$ reflect environmental and ecological conditions and thus may be able to reveal sourcing within a catchment, provided it is characterized by a gradient in environmental conditions. The carbon isotopic signatures of plant waxes in river sediment has been used to trace the evolving character of suspended sediment $\mathrm{OC}$ between mountain-front tributaries and the river mouth, based on the contrast between $\mathrm{C}_{3}$ upland 
vegetation and $\mathrm{C}_{4}$ lowland vegetation (Galy et al., 2011), between river and estuary (Medeiros et al., 2012) and between $C_{3}$ forest and petrogenic sources (Häggi et al., 2016). Sourcing has also been differentiated based on hydrogen isotopes in precipitation that vary spatially within catchments, including with elevation (Galy et al., 2011; Häggi et al., 2016; Hoffmann et al., 2016; Ponton et al., 2014). A few studies are beginning to combine information from different compound classes as erosion and preservation pathways may differ between compounds, for example with diterpenoids (derived from conifers) being over contributed relative to triterpenoids (derived from angiosperms; Giri et al., 2015) or with $n$-alkanoic acids and $n$ alcohols having a more rapid response to changes in runoff and thus more local input relative to $n$-alkanes (Hemingway et al., 2016). Studies of river suspended sediment using radiocarbon have demonstrated the potential for pre-aged carbon to contribute to the $n$-alkane load (including rockderived sources, that are radiocarbon dead), whereas the radiocarbon ages for the $n$-alkanoic acids suggest considerably less (but not negligible) influence from soil storage (Galy and Eglinton, 2011; Kusch et al., 2010; Tao et al., 2015). However, despite the complementary information provided by different isotope systems and biomarker compounds, few fluvial studies have combined information from C and $\mathrm{H}$ isotopes (Galy et al., 2011; Häggi et al., 2016), and fewer have compared $n$-alkane and $n$-alkanoic acid compound classes (Hemingway et al., 2016) or $\mathrm{C}$ and $\mathrm{H}$ isotope systems in multiple compound classes (Chikaraishi et al., 2005).

In a series of biomarker studies along the eastern flank of the Andes in Perú, the authors of this paper and other collaborators have shown that biomarkers record aspects of environment and that these properties may tag biospheric carbon in fluvial transit. The altitude effect in the isotopic composition of precipitation has been demonstrated locally in precipitation, plant waters, and plant wax $n$-alkanes and $n$-alkanoic acids in the canopy leaves of the modern forest (Feakins et 
al., 2016a). Similarly, the $\delta \mathrm{D}$ value of plant wax $\mathrm{C}_{28} n$-alkanoic acids transported by rivers in the Madre de Dios River network records the altitude effect in soils in the same catchment (Ponton et al., 2014). Lignin biomarkers trace soil degradation and erosion processes represented in river sediments (Feng et al., 2016), and also signal that soil-river is the dominant pathway for most organic carbon including plant waxes (rather than direct input of plant leaves or leaf wax aerosols into the river). More recently it has been shown that plant leaf (Asner et al., 2014) and plant leaf wax $n$-alkane and $n$-alkanoic acids (Wu et al., 2017) are ${ }^{13} \mathrm{C}$-enriched with altitude. This pattern in bulk leaves has also been seen in other wet tropical montane forests (Asner and Martin, 2016; Körner et al., 1988), but can be complicated elsewhere by the stronger control exerted by aridity as shown in bulk leaves and leaf wax $n$-alkanes (Diefendorf et al., 2010), and in tropical lowlands, there can be a significant contribution from species using the $\mathrm{C}_{4}$ pathway (Galy et al., 2011; Häggi et al., 2016; Hemingway et al., 2016). The utility of $\delta^{13} \mathrm{C}_{\mathrm{wax}}$ as an altitudinal sourcing tracer has not yet been demonstrated in upland soils and river exported sediments, although plant-based evidence indicates potential (Wu et al., 2017).

Here, we present a dual isotope $(\mathrm{C}$ and $\mathrm{H})$ and a dual compound class ( $n$-alkanes and $n$-alkanoic acid) study of soils and river sediments in the Madre de Dios River basin. We hypothesize that the trends seen in plants for D-depletion (Feakins et al., 2016a) and ${ }^{13} \mathrm{C}$-enrichment with altitude both in bulk leaves (Asner et al., 2014) and leaf wax $n$-alkanes and $n$-alkanoic acids (Wu et al., 2017) from canopy leaves, will be imprinted into the soils and allow us to track inputs to the river. We seek to test whether both $n$-alkanes and $n$-alkanoic acids in soils equally record the canopy vegetation trends reported for $\delta \mathrm{D}$ (Feakins et al., 2016a) and $\delta^{13} \mathrm{C}$ (Wu et al., 2017), or whether the post-mortem biogeochemical processes differ between the two leaf wax compound classes within soil storage. Further, we seek to describe how those signals are represented in 
river suspended sediments. We take a detailed elevation sampling approach to the soils and river network, with new analyses of the same sample set reported in prior studies of $n$-alkanoic acid $\delta \mathrm{D}$ (Ponton et al., 2014) and lignin (Feng et al., 2016) from the region. Through these observations we gather information about biogeochemical processes from plant-to-soil-to-river, in a large tropical montane river system. This dual isotope approach complements prior work on another large tropical river network, the Congo River basin (Hemingway et al., 2016), which has a lowland catchment. We seek to contribute to understanding the processes of sedimentary integration identified by the community as major gaps in knowledge in several recent review papers for both plant wax hydrogen (Sachse et al., 2012) and carbon isotopes (Diefendorf and Freimuth, 2017). The ultimate goals of this dual isotope, dual compound class and soil-to-river approach are to 1) better understand processes along source-to-sink pathways in the plant wax component of the carbon cycle (Clark et al., 2017; Galy et al., 2015), 2) aid interpretations of sedimentary records from rivers draining large, tropical montane watersheds (Bendle et al., 2010; Freeman and Colarusso, 2001; Hein et al., 2017); and 3) understand the signatures of elevation encoded in plant waxes in soils towards paleoaltimetry applications including a familiar hydrogen isotope approach (Kar et al., 2016; Polissar et al., 2009; Zhuang et al., 2015) here combined with carbon isotopes showing potential for dual-isotope plant wax paleoaltimetry.

\section{Materials and Methods}

\subsection{Study area}

Our study area is in the Cusco and Madre de Dios regions of Perú, from the mountainous terrain along the eastern flank of the Andes to the extensive Amazon lowland floodplain (Fig. 1a). The South American Low Level Jet brings atmospheric moisture westward, and together with the steep topography along the eastern flank of the Andes, drives high mean annual precipitation 
(MAP; $1.5-5 \mathrm{~m} \mathrm{yr}^{-1}$ ) in the study region (Killeen et al., 2007). High MAP supports lush tropical forests, with highly-biodiverse tropical rain forests in the lowlands transitioning into tropical montane cloud forests at $c .1 .5 \mathrm{~km}$ above sea level (asl), where precipitation peaks (Halladay et al., 2012). Above the tree line at c. $3.5 \mathrm{~km}$ asl, vegetation is dominated by puna grassland and shrubland. The catchment is drained by the Madre de Dios River which feeds into the Madeira River, a major Amazon tributary.

\subsection{Field methods}

\subsubsection{Soil samples}

Soil samples were previously collected from 14 well-studied forest plots along the elevation transect spanning $194-3644 \mathrm{~m}$ asl (Fig. 1a, b). All sites are covered with tropical rain forests or montane cloud forests, except the uppermost site (TC), just above the tree line and dominated by puna grassland. Subsamples were taken from five soil pits $(40 \times 40 \mathrm{~cm})$ distributed systematically across each 1 ha plot and homogenized. Samples were taken from the soil organic (O) and mineral (M) horizon, differentiated by color, where the top $10 \mathrm{~cm}$ from each horizon was sampled. If the $\mathrm{O}$ horizon was less than $10 \mathrm{~cm}$ thick (O-horizon thickness ranges from $0.7-22.8$ $\mathrm{cm}$ and generally increases with elevation; Table 1), then the entire $\mathrm{O}$ horizon was sampled. These soil samples were previously analyzed for the $\delta \mathrm{D}$ value of the $\mathrm{C}_{28} n$-alkanoic acid from the M horizon only (Ponton et al., 2014) and for bulk organic carbon content (OC\%) and lignin biomarker distribution, for both $\mathrm{O}$ and $\mathrm{M}$ horizon (Feng et al., 2016). Here we add $\delta^{13} \mathrm{C}$ for the $n$ alkanes and $n$-alkanoic acids in both horizons, $\delta \mathrm{D}$ for the $n$-alkanes in both horizons, and $\delta \mathrm{D}$ values for the $n$-alkanoic acids in the $\mathrm{O}$ horizon, complementing the $\mathrm{M}$ horizon data from Ponton et al. (2014) that we reanalyze here for analytical consistency (Appendix A). 


\subsubsection{River suspended sediment samples}

River water samples were previously collected from the Kosñipata and Madre de Dios River main stem and major tributaries during March (wet season) and August (dry season) 2013 (Fig. 1). We followed the river downstream with samples collected at point locations across a range of elevations (c. 180 - 2280 masl) but representing contributions from the catchment above the sampling point. For example, at Wayqecha, our highest river sampling point (2271 masl), the river drains a catchment size of c. $50 \mathrm{~km}^{2}$ with elevation that extends up to 3933 masl (mean catchment elevation $=3203 \mathrm{~m}$ asl). Here, the Kosñipata River was turbulent and well-mixed,

carrying a high sediment load in the wet season but very little in the dry season $\left(63\right.$ and $6 \mathrm{~g} \mathrm{~L}^{-1}$ at WAY and SP in the wet season, vs. $0.03 \mathrm{~g} \mathrm{~L}^{-1}$ at SP in the dry season). In these mountain streams, suspended sediment sampling was performed from the river bank using a 10 L bucket. At lower elevations where the Madre de Dios River was navigable, suspended sediment samples were collected from the middle of the river, where the velocities are the fastest, accessed by a small boat, repeatedly returning to the same location in the river (tracked by Global Positioning System) and sampling surface water samples using a $10 \mathrm{~L}$ bucket. We collected depth profiles in the lowland river with the same river navigation methods and using specially-designed $10 \mathrm{~L}$ horizontal isokinetic depth-sampler with a fin for orientation and a pneumatic trap door closure mechanism. At our lowest river sampling point near Puerto Maldonado (CMD35; $180 \mathrm{~m}$ asl), the mainstem drains a catchment size of c. $75,000 \mathrm{~km}^{2}$ with elevation that extends up to $6062 \mathrm{~m}$ asl (mean catchment elevation $=1178 \mathrm{~m}$ asl), after the confluence with the Inambari River $(\# 44$, in Fig 1a) which drains the very highest regions. Within the river network, there is therefore considerable heterogeneity in catchment hypsometry, only partially reflected in the catchment 
mean elevation reported in addition to sampling elevation and distance along river channel (calculated as km upstream from Puerto Maldonado).

At each river sampling location, large volumes of river water $(60-180 \mathrm{~L})$ were collected in $10 \mathrm{~L}$ increments; $100 \%$ of the sample was transferred into wine bags with a liner of ethylene vinyl alcohol (EVOH). Bags were transported and stored in the dark prior to filtering. Water samples were filtered within $12 \mathrm{hrs}$ at $0.2 \mu \mathrm{m}$ on polyethersulfone (PES) filters (90 and $147 \mathrm{~mm}$ diameter) using pressurized filtration units, similar to Galy et al. (2011). Filters containing the particulate organic matter (POM) were stored in Whirlpak bags under cool conditions during the 2-week fieldwork in remote areas until transport back to the laboratory for refrigeration. The dissolved fraction $(<0.2 \mu \mathrm{m})$ was not analyzed in this study. In the laboratory, the POM was rinsed off the filter with milliQ water and subsequently freeze-dried using a Virtis $2 \mathrm{k}$ unit. Dry samples were disaggregated and material coarser than $1 \mathrm{~mm}$ was removed using a sieve. Coarse material was infrequently recovered and comprised occasional leaf and wood debris. The organic matter content of the sieved suspended sediments $(0.2-1000 \mu \mathrm{m})$ constitutes the POM. These are the same river suspended sediment samples collected, extracted, and purified as reported in Ponton et al. (2014), where $\delta \mathrm{D}$ values of $\mathrm{C}_{28} n$-alkanoic acids only were presented. Those samples are reanalyzed here for dual compound class ( $n$-alkane and $n$-alkanoic acid) quantification and for dual $\mathrm{C}$ and $\mathrm{H}$ isotopic composition analysis on both compound classes. We also add results from depth profile samples, representing some of the only compound-specific stable isotope data reported to date from river depth profiles.

\subsection{Laboratory methods}

2.3.1. Lipid extraction and compound identification 
Total lipid extracts (TLE) were extracted from freeze-dried and homogenized samples with 9:1 v/v dichloromethane (DCM) to methanol (MeOH) using an Accelerated Solvent Extraction system (ASE 350, Dionex), at $100^{\circ} \mathrm{C}$ and $1500 \mathrm{psi}$ for 2 cycles of 15 mins. TLE were then separated by column chromatography through $\mathrm{LC}-\mathrm{NH}_{2}$ gel into a neutral (containing $n$-alkanes) and acid (containing $n$-alkanoic acids) fraction, eluted by $2: 1 \mathrm{v} / \mathrm{v}$ DCM to isopropanol and $4 \%$ formic acid in diethyl ether respectively. The neutral fraction was eluted through silica gel using hexane, DCM, and methanol, with the hexane fraction containing the $n$-alkanes. The acid fraction was methylated using $\mathrm{MeOH}$ of known $\mathrm{C}$ and $\mathrm{H}$ stable isotopic compositions in $\mathrm{HCl}$ $(19: 1 \mathrm{v} / \mathrm{v})$ at $70^{\circ} \mathrm{C}$ for $12 \mathrm{~h}$. The product was then diluted with milliQ water and partitioned in hexane, which was then further separated by column chromatography through $5 \%$ waterdeactivated silica gel, using hexane and DCM respectively. DCM elutes the fatty acid methyl esters (FAMEs). The fractions that contained the $n$-alkanes and FAMEs were blown dry with $\mathrm{N}_{2}$ gas and dissolved in hexane ready for compound identification and quantification using gas chromatography (Agilent 6890) coupled with mass-selective detector (Agilent 5973) and flame ionization detection (GC-MS/FID). The instrument was equipped with a Rxi-5 ms column (30 m x $0.25 \mathrm{~mm}$, film thickness $0.25 \mu \mathrm{m}$ ) with column flow split between MS and FID. Absolute abundance was calculated using a calibration curve of an in-house standard mixture of $n$-alkanes and $n$-alkanoic acids and their peak area response on the FID, with the same analytical conditions between standard and sample. For those samples where an unresolved complex mixture was found during GC-MS analysis of the $n$-alkane fraction, the $n$-alkanes were isolated by ureaadduction prior to isotopic analyses.

We report the concentration of individual homologues and the sum of the $\mathrm{C}_{23^{-3} 3} n$-alkanes ( $\sum$ alk) and the $\mathrm{C}_{22-32} n$-alkanoic acids ( ( acid) on a $\mu \mathrm{g} \mathrm{g}^{-1}$ sediment and $\mu \mathrm{g} \mathrm{g}^{-1} \mathrm{OC}$ basis ( $\Lambda$ alk and 
$\Lambda$ acid), summing compounds likely to be mostly plant wax derived based on both reported plant wax distributions (Feakins et al., 2016b) as well as the consistency of the isotopic composition of these homologues in the sedimentary samples studied here. We also calculate the average chain length (ACL) and carbon preference index (CPI) of $n$-alkanes and $n$-alkanoic acids using the following equations:

$\mathrm{ACL}=\Sigma\left(n \times\left[\mathrm{C}_{\mathrm{n}}\right]\right) / \Sigma\left[\mathrm{C}_{\mathrm{n}}\right]$

and

$\mathrm{CPI}=2\left[\mathrm{C}_{\mathrm{n}}\right] /\left(\left[\mathrm{C}_{\mathrm{n}-1}\right]+\left[\mathrm{C}_{\mathrm{n}+1}\right]\right)$

where $n$ indicates the chain length, $n=23-33$ for $n$-alkanes and $n=22-32$ for $n$-alkanoic acids. We also report the modal chain length $\left(\mathrm{C}_{\max }\right)$. These data are compared to sediment load, OC concentrations, lignin biomarkers and specific surface area (SSA) previously reported in Feng et al. (2016).

\subsubsection{Compound-specific isotopic analysis}

Carbon and hydrogen isotopic compositions of individual compounds were measured using gas chromatography - isotopic ratio mass spectrometry (GC-IRMS; Thermo Scientific Trace gas chromatograph connected to a Delta V Plus mass spectrometer, via an Isolink combustion furnace at $1000^{\circ} \mathrm{C}$ for $\delta^{13} \mathrm{C}$ measurement, and an Isolink pyrolysis furnace at $1400^{\circ} \mathrm{C}$ for $\delta \mathrm{D}$ measurement). We checked the linearity in isotopic determination across a range of peak amplitude $(1-10 \mathrm{~V})$ daily, and only the measurements from compounds with peak amplitudes within the range of linearity were accepted. $\delta^{13} \mathrm{C}$ values were normalized to the Vienna Pee Dee Belemnite (VPDB) standard, and $\delta$ D values were normalized to the Vienna Standard Mean 
Ocean Water/Standard Light Antarctic Precipitation (VSMOW/SLAP) standard, by comparing with an external standard, the A3-mix (supplied by A. Schimmelmann, Indiana University), containing $15 n$-alkane compounds $\left(\mathrm{C}_{16}-\mathrm{C}_{30}\right)$ with $\delta^{13} \mathrm{C}$ and $\delta$ D values spanning -33.3 to $-28.6 \%$, and -9 to $-254 \%$ respectively, with RMS uncertainties better than 0.2 and $5 \%$, representing the dominant component of analytical uncertainty. We correct measured $n$-alkanoic acid methyl esters by mass balance for the added methyl group $\left(\delta^{13} \mathrm{C}-25.45 \pm 0.37 \%\right.$, determined offline by combustion of methanol, and $\delta \mathrm{D}-198.3 \pm 3.9 \%$, determined by methylation of a phthalic acid standard supplied by A. Schimmelmann) (Lee et al., 2017) to report the $\delta^{13} \mathrm{C}$ and $\delta \mathrm{D}$ values of $n$-alkanoic acids.

\subsubsection{Catchment hypsometry}

We delineated the Madre de Dios River network and catchments of river sediment samples (Fig. 1a) in ArcGIS using 3 arc-second (c. $90 \mathrm{~m}$ ) resolution Shuttle Radar Topography Mission (SRTM) digital elevation model (DEM; Fig. 1b) (Jarvis et al., 2008). River profile and elevation distributions were then determined from the delineated catchments. These data were used to identify the catchment mean elevation of individual river suspended sediment samples. 


\section{Results}

\subsection{Concentrations of organic carbon and plant wax biomarkers in soils}

Plant wax biomarker concentrations vary by two orders of magnitude in sampled soils. We find the expected distributions of $n$-alkane and $n$-alkanoic acid homologues indicative of plant wax sources and report the concentrations for individual homologues (Appendix A). We sum the homologues to report total compound class concentrations. In the $\mathrm{O}$ horizon, $\sum$ alk range from 2 $-144($ median $=22.5) \mu \mathrm{g} \mathrm{g}^{-1}$ and $\sum$ acid range from $14-290($ median $=109) \mu \mathrm{g} \mathrm{g}^{-1}$. In the $\mathrm{M}$ horizon, $\sum$ alk values range from $3-24($ median $=11) \mu \mathrm{g} \mathrm{g}^{-1}$ and $\sum$ acid from $12-422($ median $=$ 71) $\mu \mathrm{g} \mathrm{g}^{-1}$.

The $\sum$ alk is less abundant than $\sum$ acid and both decrease in concentration between the $\mathrm{O}$ and the $\mathrm{M}$ horizon at each site. We find no systematic change in $\sum$ acid $/ \sum$ alk between the $\mathrm{O}$ and $\mathrm{M}$ horizons on a site-by-site basis or along the elevation profile, suggesting no uniform difference in net changes in inputs and preservation.

Considering plant wax as a proportion of soil organic matter $\left(\Lambda \mathrm{alk}=\sum \mathrm{alk} / \mathrm{OC}\right)$ accounts for part of the variability in plant wax concentrations. OC varies by an order of magnitude from $4.3 \%$ to $38.8 \%$ in the $\mathrm{O}$ horizon $(\mathrm{OC}<10 \%$ at $\mathrm{TP} 3, \mathrm{TP} 4, \mathrm{SP} 1)$ and $1.9 \%$ to $13.0 \%$ in the $\mathrm{M}$ horizon $(\mathrm{OC}>$ $10 \%$ at WAY) as reported in Feng et al. (2016). We find $\Lambda$ alk ranges from $56-889$ (median $=$ 122) $\mu \mathrm{g} \mathrm{g}^{-1} \mathrm{OC}$, and $\Lambda$ acid ranges from $154-1330$ (median $\left.=723\right) \mu \mathrm{g} \mathrm{g}^{-1} \mathrm{OC}$ in the O-horizon. $\Lambda$ alk ranges from $116-320($ median $=181) \mu \mathrm{g} \mathrm{g}^{-1} \mathrm{OC}$, and $\Lambda$ acid ranges from $384-5485$ $($ median $=1140) \mu \mathrm{g} \mathrm{g}^{-1} \mathrm{OC}$ in the M-horizon (Appendix A). Overall plant wax concentrations vary by an order of magnitude more than bulk soil organic matter concentrations. Some higher elevation sites have higher concentrations of plant waxes (one site TU4 has exceptionally high 
concentrations). However, the altitudinal trend is small compared to the scatter between sites, soils being notoriously heterogeneous. Vertically within soils we find a decrease in $n$-alkane and $n$-alkanoic acid concentration between $\mathrm{O}$ and $\mathrm{M}$ horizons, but $n$-alkanes and $n$-alkanoic acids represent an increasing (but still trace) component of organic matter in deeper layers of soil.

\subsection{Altitude effect in plant wax $\delta^{13} \mathrm{C}$ and $\delta \mathrm{D}$ in soils}

We measured $\delta^{13} \mathrm{C}$ and $\delta \mathrm{D}$ values of odd chain length $n$-alkanes $\left(\mathrm{C}_{27}-\mathrm{C}_{31}\right)$ and even chain length $n$-alkanoic acids $\left(\mathrm{C}_{22}-\mathrm{C}_{32}\right)$ in soils across the elevation transect (as homologue abundances allow). All plant wax homologues in both $\mathrm{O}$ and $\mathrm{M}$ horizons show the same trends: an increase in $\delta^{13} \mathrm{C}$ and a decrease in $\delta \mathrm{D}$ values with increasing elevation (except the $\mathrm{C}_{27} n$ alkanes which are present in low concentrations; Appendix A). We focus on $\mathrm{C}_{29} n$-alkanes $\left(\delta^{13} \mathrm{C}_{29 \text { alk }}\right)$ and $\mathrm{C}_{30} n$-alkanoic acids $\left(\delta^{13} \mathrm{C}_{30 \text { acid }}\right)$ as they are the most abundant long-chain compounds in each class, both in soils (this study, Appendix A) and canopy leaves (Feakins et al., 2016a; Feakins et al., 2016b). $\delta^{13} \mathrm{C}_{29 a l k}$ increases with elevation in soil $\mathrm{O}$ and $\mathrm{M}$ horizons $(+1.37$ and $+1.75 \% \mathrm{~km}^{-1}$ respectively) with gradients similar to canopy leaves within uncertainties (Wu et al., 2017), but with a $c .+2 \%$ increase from leaves to soil (Fig. $2 \mathrm{a}) . \delta^{13} \mathrm{C}_{30 \text { acid }}$ also increases with elevation $\left(+1.06\right.$ and $+1.31 \% \mathrm{~km}^{-1}$ in $\mathrm{O}$ and $\mathrm{M}$ horizons respectively; Fig. $\left.2 \mathrm{~b}\right)$. In canopy leaves (Fig 2b), the elevation relation was not statistically significant given the small number of forest plots sampled for $\delta^{13} \mathrm{C}_{30 \text { acid }}$ analyses (Wu et al., 2017), but site mean plant values are similar to soils (Fig 3b). Comparing the two soil horizons, we find a $c .+1 \%$ increase on average from $\mathrm{O}$ to $\mathrm{M}$ horizon in both $\mathrm{C}_{29} n$-alkane and $\mathrm{C}_{30} n$-alkanoic acid (Fig. 2a, b). This $\mathrm{O}$ to $\mathrm{M}$ offset is not apparent in the lowest elevation sites (TP3 and TP4), but the O horizon at these two sites is very thin $(0.7-2.5 \mathrm{~cm}$; Table 1$)$, and the samples collected show relatively low OC\% $(4.3-9.3 \%)$, thus not meeting the typical $>10 \%$ criterion for an $\mathrm{O}$ horizon (Feng et al., 2016). 
$\delta \mathrm{D}_{29 a l k}$ decreases with elevation in soil $\mathrm{O}$ and $\mathrm{M}$ horizons ( -13.2 and $-9.7 \% \mathrm{~km}^{-1}$ respectively) with shallower but similar gradients (within the large uncertainties) to canopy leaves ( $-16.4 \%$ o $\mathrm{km}^{-1}$; Fig. $\left.2 \mathrm{c}\right)$ and with similar absolute values. $\delta \mathrm{D}_{30 \text { acid }}$ in both horizons show the same trend with similar slopes ( -10.1 and $-11.8 \% \mathrm{~km}^{-1}$ for $\mathrm{O}$ and $\mathrm{M}$ horizon respectively; Fig. $\left.2 \mathrm{~d}\right)$. In contrast to $\delta^{13} \mathrm{C}$, we do not observe systematic isotopic offsets in $\delta \mathrm{D}$ values between plant and soil, or between $\mathrm{O}$ and $\mathrm{M}$ horizons in either compound classes (Fig. 2c, d) although for the highest altitude plant site, the site mean plant $\delta \mathrm{D}_{29 a l k}$ value is more negative than soils, which has the effect of steepening the apparent plant slope, although this is not well defined by 5 sites resulting in a large uncertainty (Fig. 2c). Overall, the trend with altitude is the major finding for both isotopes and compound classes for the catchment scale interpretations (Fig. 2).

\subsection{Altitude effect in plant wax $\delta^{13} \mathrm{C}$ and $\delta \mathrm{D}$ in surface river suspended sediments}

We measured $\delta^{13} \mathrm{C}$ and $\delta \mathrm{D}$ values of odd chain length $n$-alkanes $\left(\mathrm{C}_{27}-\mathrm{C}_{31}\right)$ and even chain length $n$-alkanoic acids $\left(\mathrm{C}_{24}-\mathrm{C}_{30}\right.$; as homologue concentrations allow) in river suspended sediment collected across the elevation transect (Appendix A). We note that molecular abundance distributions of both compound classes, and the isotopic similarities across dominant homologues, are consistent with those found in soils (Appendix A). All plant wax homologues show the same trends: an increase in $\delta^{13} \mathrm{C}$ and a decrease in $\delta \mathrm{D}$ values with increasing elevation (except the $\mathrm{C}_{27} n$-alkane, which is more ${ }^{13} \mathrm{C}$-enriched, Appendix A). Here we focus on $\mathrm{C}_{29} n$ alkanes $\left(\delta^{13} \mathrm{C}_{29 a \mathrm{alk}}\right)$ and $\mathrm{C}_{30} n$-alkanoic acids $\left(\delta^{13} \mathrm{C}_{30 \text { acid }}\right)$ as they are the most abundant long-chain compounds in each class in rivers and soils, as well as in canopy leaves as noted above (Feakins et al., 2016a; Feakins et al., 2016b). In the wet season $\delta^{13} \mathrm{C}$ values increase with elevation in rivers for both $\delta^{13} \mathrm{C}_{29 a \text { alk }}\left(+1.01 \% \mathrm{~km}^{-1}\right.$; Fig. 3a) and $\delta^{13} \mathrm{C}_{30 \text { acid }}\left(+0.96 \% \mathrm{~km}^{-1}\right.$; Fig. 3b). We find very little Andean export in the dry season, i.e. sediment loads of OC and $\Sigma_{\text {alk }}$ and $\Sigma_{\text {acid }}$ are lower 
in the Andean rivers during the dry season relative to the wet season and relative to the downstream reaches (Table 2). Following this, $\delta^{13} \mathrm{C}$ values increase less with sampling elevation in the dry season, but the trend is not sufficiently described given the small sample size $(\mathrm{n}<7)$ available. Availability of dry-season suspended sediments was limited in the upland, because even very large samples ( $>300 \mathrm{~L}$ of river water at the uppermost sampling point) did not yield sufficient plant wax for isotopic analyses.

\subsubsection{River depth profiles}

Sediment settling within river channels leads to higher sediment loads at depth, with significant effects in the rivers studied here, which range up to $12 \mathrm{~m}$ deep (Fig. 4a). OC concentrations tend to decline with depth, however there is a 'woody undercurrent' of visible coarse plant debris just above the peak in sediment load within some deep channels (Fig. 4b, Feng et al., 2016). OC variations largely control $n$-alkane concentrations, with $\Lambda_{\text {alk }}$ varying by less than a factor of two in most depth profiles, apart from high $\Lambda_{\text {alk }}$ in the surface and deepest samples of one profile (CMD 25, Fig. 4c). We do not have robust quantification data for the $n$-alkanoic acids; however they are more abundant than the $n$-alkanes. The finer sediments in the upper water column have higher specific surface area (SSA; Fig. 4e; Feng et al., 2016). CPI $_{\text {alk }}$ varies between location and depth, but tends to decrease toward the surface, suggesting transport of more degraded $n$-alkanes in association with fine grains with high SSA (Fig. 4f), such as those from the weathered soils. This is consistent with evidence of in-river depth differentiation in $\delta^{13} \mathrm{C}_{\text {alk }}$ values (Fig. $\left.4 \mathrm{f}\right)$ : the upper samples are consistent with degraded $\mathrm{M}$ horizons, whereas the deep samples are ${ }^{13} \mathrm{C}$ depleted and this might reflect the 'woody undercurrent' with overprinting of some larger, fresher material from plants and from the O horizon. We find essentially no sorting of $\delta^{13} \mathrm{C}_{30 \text { acid }}$ (Fig. 4g), $\delta \mathrm{D}_{\text {acid }}$ (Fig. 4h), or $\delta \mathrm{D}_{\text {alk }}$ (Fig. 4i) consistent with an absence of offset 
between soil $\mathrm{O}$ and $\mathrm{M}$ horizons. For $\delta^{13} \mathrm{C}_{\text {alk }}$, it appears that the differential effects between $\mathrm{O}$ and M horizon also complicates assessment of sediment sourcing in rivers, whereas $\delta^{13} \mathrm{C}$ values of the $n$-alkanoic acids and the $\delta \mathrm{D}$ values of both compound classes provide elevation markers immune to these effects. 


\section{Discussion}

\subsection{Altitude effect in soils}

The sensitivity of plant wax $\delta^{13} \mathrm{C}$ values in soils to elevation (Fig. 2a, b) provides new evidence that carbon isotopes may be useful as an elevation proxy in paleosols and for sedimentary sourcing studies. This study confirms that the slope of canopy plant wax $\delta^{13} \mathrm{C}$ values with altitude (Wu et al., 2017) is robustly captured in soils here. The major caveat with this approach is that aridity is a larger factor in carbon isotope fractionations relative to elevation effects (Diefendorf et al., 2010) and this can confound an altitude effect; for example a prior application of plant wax $\delta^{13} \mathrm{C}$ in soils on Mt. Gongga, China, found the patterns to be dominated by aridity (Wei and Jia, 2009). However, in the very wet region of the Madre de Dios, the altitude sensitivity encoded in soils provides a robust signal that can be used for our catchment sourcing questions.

The altitude effect in hydrogen isotopes in precipitation has been established in plant wax (Bai et al., 2011) and applied for paleoaltimetry (Polissar et al., 2009). Such an elevation effect has already been reported for plant wax $\delta \mathrm{D}$ in the tree canopy (Feakins et al., 2016a) and soils (Ponton et al., 2014) in the Madre de Dios. This study extends those findings, confirming the presence of the altitude effect in dual plant wax compound classes in soils, i.e. that it is robust to the early diagenesis changes between leaf and soil. Thus, we find both compound classes and both isotope systems have potential for 'tagging' the elevation of origin.

Overall, the altitude trends seen in prior tree canopy surveys (Feakins et al., 2016a; Wu et al., 2017) are found to be reproduced in tree canopy and in soil $\mathrm{O}$ and $\mathrm{M}$ horizons for $\delta^{13} \mathrm{C}$ of $n$ alkanoic acids and $\delta \mathrm{D}$ values of both $n$-alkanoic acids and $n$-alkanes here (Fig. 2 ). But, while the 
carbon isotopic trend in the canopy is indeed transferred to soils, there is a $>2 \%{ }^{13} \mathrm{C}$-enrichment in $n$-alkanes in soils relative to leaves (considered separately below). Considering the greater plant wax stock in soils relative to tree canopy, the multi-centennial age of most river-exported plant wax (Galy and Eglinton, 2011; Kusch et al., 2010) and the coherence between soils and river samples (considered later), the soils, especially the M horizon, probably represent the major source of plant wax to the river. Thus, we find the soil-based calibrations most relevant for interpretation of catchment sourcing.

4.1.1. Offset in $n$-alkane $\delta^{13} \mathrm{C}$ values between canopy and soils

What may explain the offset in $\delta^{13} \mathrm{C}$ values (Fig. 2a) between tree canopy $n$-alkanes and soils and between $\mathrm{O}$ and $\mathrm{M}$ horizon in the Andes? First, the Suess effect (anthropogenic alteration of the $\delta^{13} \mathrm{C}_{\text {of }} \mathrm{CO}_{2}$ in the atmosphere due to the combustion of fossil fuels) has lowered the $\delta^{13} \mathrm{C}$ of the atmosphere between $c$. $-6.4 \%$ in $1750 \mathrm{AD}$ (Friedli et al., 1986) to $-8.3 \%$ in 2013 , when samples were collected - amounting to a lowering of $-1.9 \%$. Today's atmosphere is the substrate for modern plant leaves, whereas the $\mathrm{OC}$ in soil was fixed from an atmosphere with higher $\delta^{13} \mathrm{C}$. Plant wax in the O horizon likely integrates several recent decades, and since 1960 there has been a $1 \%$ lowering of the atmospheric $\delta^{13} \mathrm{C}$ (Friedli et al., 1986) and thus we might expect up to a $-1 \%$ offset of the $\mathrm{O}$ horizon from canopy leaves based on the Suess effect alone. Plant wax in M horizons may be much older, perhaps integrating several centuries, including (but likely not exclusively) preindustrial and thus we might expect up to a $-2 \%$ offset between the canopy and the M horizon. However additional factors still must be invoked to explain the offsets as not all soil $\mathrm{O}$ and M horizon carbon dates from prior to 1960 and 1750 respectively. 
Degradation processes may account for part of the offset between the canopy, $\mathrm{O}$ horizon and $\mathrm{M}$ horizon. Indeed this magnitude of effect is possible with $>2 \%$ increase in $n$-alkane $\delta^{13} \mathrm{C}$ values reported elsewhere between fresh leaves and leaf litter (Nguyen Tu et al., 2004). Degradation gradients exist along the elevation transect in the Madre de Dios; for example, the $\mathrm{O}$ horizon is thinner and has a lower OC content at the lowest elevation site, in addition to local variations associated with waterlogging. Fungal communities have been shown to add $n$-alkanes at depth (Marseille et al., 1999) and could carry a distinct carbon isotopic signature, though fractionations are unknown.

Other inputs to soils should be considered. Understory plant wax contributions to soils are unlikely to drive the offset as productivity is lower than that of the canopy and ${ }^{13} \mathrm{C}$-depleted values due to respired carbon would be expected, counter to the observed offset. Root wax contributions to soils are possible, as agricultural studies have reported that root derived lipids may be better preserved than leaf lipids in soils and may be ${ }^{13} \mathrm{C}$-enriched (Rasse et al., 2005; Wiesenberg et al., 2004). Root wax inputs were not characterized as part of this study, and we note that root species identification in a mixed rainforest is difficult, in contrast to crop monoculture. Fine root productivity increases with altitude in this region (Girardin et al., 2013), so root wax inputs may be greater at higher altitudes, and this could contribute to the different slopes of $\delta^{13} \mathrm{C}$ for the $\mathrm{O}$ and $\mathrm{M}$ horizon (Fig. $2 \mathrm{a}, \mathrm{b}$ ). However, fresh root production would be unlikely to explain the offset as the Suess effect would act counter to the direction of offset observed.

Generally, plant wax concentrations reveal an increase in $\Lambda_{\text {alk }}$ and $\Lambda_{\text {acid }}$ by about a factor of two between the $\mathrm{O}$ and the $\mathrm{M}$ horizon, which likely reflects the slower rates of loss relative to other compounds in soils such as cellulose (Kögel-Knabner and Amelung, 2013; Schmidt et al., 2011) 
and explains the importance of waxes as geological biomarkers (Eglinton and Eglinton, 2008). A couple of studies have indicated that there can be deep soil additions of $n$-alkanes from fungi (Marseille et al., 1999) and of $n$-alkanoic acids from roots (Wiesenberg et al., 2004), although it is not clear how widespread such inputs are, and how much this may confound the "leaf" wax environmental interpretation. How inputs and preservation vary between compound classes merits further study.

\subsection{The river-transported signal of plant wax $\delta^{13} \mathrm{C}$ and $\delta \mathrm{D}$}

During the wet season, plant wax $\delta^{13} \mathrm{C}$ and $\delta \mathrm{D}$ values in both compound classes in river suspended sediments (surface water) correlate with mean catchment elevation (blue symbols and regression, $\mathrm{p}<0.001$; Fig. 3), following similar patterns as found in soils (both soil $\mathrm{O}$ and $\mathrm{M}$ regression envelopes shown for comparison; Fig. 3). A previous study of $\delta \mathrm{D}$ values of $\mathrm{C}_{28} n$ alkanoic acids in the same samples used the median catchment elevation as the central estimate of the skewed hypsometric distribution (Ponton et al., 2014). Here we analyzed the river data with both the median and the mean catchment elevation (Appendix A), and we find catchment mean elevation best represents the catchment sourcing (higher $\mathrm{R}^{2}$ by $0.11-0.25$ ), which implies averaging of all altitudes uniformly. This general interpretation applies to both $n$-alkanes and $n$ alkanoic acids and both hydrogen and carbon isotopic composition in our wet season dataset (Fig. 3). Altogether, our broader suite of measurements (dual isotope, dual compound class) supports the earlier suggestion that plant waxes in the Madre de Dios system record the isotopic gradients defined by their catchment elevations.

In order to explore differences from the soil-predicted regression based on catchment hypsometry represented by the catchment mean elevation (i.e. uniform integration case), we 
calculate the offset for individual river samples from the soil regression (Appendix A). In most cases the discrepancies between measured values and those predicted for uniform integration are neither large nor consistent between compound class or isotope system, for example at CICRA (821 m catchment mean elevation), we find a high altitude bias in the $\delta \mathrm{D}_{30 a c i d}$ only. Overall, we do not find a systematic bias from the uniform catchment integration case, except at the mountain front location, where there are seasonal effects, considered next.

During the dry season, sediment loads were low, especially at the Andean sites, limiting potential for plant wax analyses despite very large volume sampling, i.e. it was obvious in the field that the signal exported during the dry season has more of a lowland bias than the wet season uniform catchment integration case. Overall, the restricted elevation range and small number of the dry season plant wax isotopic data indicate non-significant relationships with catchment elevation (Fig. 3). Given the scatter in the dry season elevation trend, we compare the isotopic composition at point locations across seasons. At the mountain front location (MLC, $450 \mathrm{~m}$ asl, $2006 \mathrm{~m}$ catchment mean elevation), we observe seasonal differences, with the dry season offset from the wet by $-1.5 \%$ ( $\left.\delta^{13} \mathrm{C}_{30 \mathrm{acid}}\right),+26 \%$ ( $\left.\delta \mathrm{D}_{30 \mathrm{acid}}\right)$, and $-3 \% 0\left(\delta^{13} \mathrm{C}_{29 \mathrm{alk}}\right)$, with insufficient dry season sample for $\delta \mathrm{D}_{29 a 1 k}$ determination resulting in no comparison (Appendix A). The seasonal offsets include some inconsistency between proxies, but each indicate lowering of the locus of erosion by c. 1-2 km relative to the uniform catchment integration found in the wet season at this site (MLC wet season values were within uncertainty of soil-regression predicted values). At other locations where we have data in both seasons, the differences are not larger than analytical uncertainties.

Our two-season sampling approach demonstrates that the wet season accounts for most upland erosion within the catchment: the river is visibly turbid with sediments and plant wax $\Sigma$ alk 
concentrations are 49 and $10.2 \mu \mathrm{g} \mathrm{L}^{-1}$ at WAY and SP. In the dry season upland transport is reduced ( alk was not measurable at WAY and were just $0.1 \mu \mathrm{g} \mathrm{L}^{-1}$ at SP) and thus the locus of wax sourcing lowers. We find that when Andean erosion peaks in the wet season, catchment integration approximates uniform integration at all elevations (Fig. 3). During the dry season, Andean export diminishes, and this results in a pronounced seasonality in sourcing at the mountain-front location, corroborating the finding of Ponton et al., (2014), now with dual isotopes and compound classes. At the floodplain locations, catchment hypsometry is so skewed to the lowlands on an areal basis that the seasonal variation in Andean export is barely perceptible. Thus, we establish that there is no Andean bias in plant wax sourcing, even in the wet season, in contrast to the clastic flux carried by the river.

Analysis of biomarker distributions (Appendix A) reveals differences in degradation: downstream we observe lower CPI consistent with more weathering of $n$-alkanes during storage and remobilization in the floodplain for the $n$-alkanes overall $(\mathrm{p}<0.01)$ and especially in the wet season $(\mathrm{p}<0.001)$. No such degradation trend is observed in the $n$-alkanoic acids. Other plant biomarkers, lignins, similarly show degradation and soil storage prior to fluvial export in this system (Feng et al., 2016). Both $n$-alkanes and $n$-alkanoic acids show a slight tendency to increased chain length in the lowlands, similar to patterns reported for plants in the catchment suggesting the river sediment composition reflects incorporation of a lowland signal in the floodplain.

\subsection{Dual isotope analysis}

If we examine soil data in dual isotope space (Fig. 5), we observe the general inverse relationship expected from the altitudinal relationships in each isotope system, and that river samples mostly 
fall on or near the dual-isotope relationship described in the transect of soil plots (Fig. 5). We note one outlier among the river samples that does not fit with the soil or river samples in dual isotope space (CMD 31; Fig. 5). The $n$-alkanes derived from CMD 31, a mainstem, lowland sample, deviate from other soil and river samples in dual isotope space, with more ${ }^{13} \mathrm{C}$ enrichment than expected based on the $\delta \mathrm{D}$ value. In addition, CMD 31 has a low CPI. $n$-Alkanes in plants and most sediments have a high CPI, whereas low CPI is generally indicative of thermal alteration and as such is indicative of petrogenic sources. Petrogenic inputs tend to drive ${ }^{13} \mathrm{C}$-enriched values which could account for the isotopic deviation here (CMD 31 is an outlier on both Fig. 3 and 5). However, this sample was from the main stem of the Madre de Dios and no influence was detected at the next station downstream station; thus this outlier was not volumetrically relevant for sourcing in this catchment. Petrogenic inputs have been documented elsewhere in sedimentary $n$-alkanes (Häggi et al., 2016; Pearson and Eglinton, 2000), and hence many studies have favored $n$-alkanoic acids for fluvial sourcing (Galy et al., 2011; Kusch et al., 2010) and paleoenvironmental reconstruction (Feakins et al., 2013; Niedermeyer et al., 2014; Tierney et al., 2008). Nevertheless, alkanes have value for fluvial sourcing (Hemingway et al., 2016) and have been widely applied for paleoenvironmental reconstructions (Freeman and Colarusso, 2001; Pagani et al., 2006; Schefuss et al., 2011; Schefuss et al., 2003). Dual isotope analysis is demonstrated here as useful validation between two 'altimeters', here confirming strong agreement overall, as well as isolating a sample with petrogenic influence (confirming the primary evidence from that sample's low CPI). Although not applicable in this forested, very wet catchment, we suggest the dual isotope approach would also be well-suited to identify and diagnose potential causes of divergence from the altitude relation in other catchments, such as inputs from a lowland $\mathrm{C}_{4}$ savanna. In other climates, aridity could also cause the altitude effect to 
be disrupted, potentially leading to both a ${ }^{13} \mathrm{C}$ - and D-enrichment (of different magnitudes); again the dual approach can provide more information than a single-isotope based system.

Other river $n$-alkane data display minor deviations from the soil relationship in dual isotope space, with a tendency to ${ }^{13} \mathrm{C}$ - and/or D-depleted values for $n$-alkanes. These offsets are not consistent with a bias in spatial integration as each isotope has opposing implications $\left({ }^{13} \mathrm{C}\right.$ depleted would imply lower elevation, while D-depleted would imply higher elevation). Generally high CPI allows us to discount a petrogenic source in most samples, although the CPI systematically declines $(\mathrm{p}<0.01)$ toward the lowland and is more scattered in the lower elevations and between tributaries (Appendix A); thus stored input from different environments or times may explain some of the scatter. Depletion of both isotopes in the same molecules may be explained if: a) the range of sources in the catchment have not been completely represented by the transect of soil samples, e.g. if a lens of ancient substrate is exported from a river bank (Householder et al., 2012; Rigsby et al., 2009), b) analytical uncertainties contribute to 'scatter' in the river samples around the regression envelope of uncertainties (with overall hydrogen isotope analytical uncertainties on the order of $5 \%$, and carbon on the order of $0.2 \%$ ) or c) point sampling of the river does not fully represent the full transport load of the river (despite contrasting two seasons, we have not accomplished sampling of detailed seasonality (Hemingway et al., 2016; Tao et al., 2015), extreme flood hydrographs (Freymond et al., 2018), or interannual variability). 


\subsection{Implications for geological and geochemical applications}

\subsubsection{Understanding plant wax sedimentary integration}

Where plant wax biomarker reconstructions are derived from large catchments with high elevation, questions have been raised about the source area represented in the downstream sedimentary deposits as well as the temporal components of erosion, storage and sedimentary sourcing (e.g., Hein et al., 2017). These questions have been summarized as "the nature of sedimentary integration" (Diefendorf and Freimuth, 2017; Sachse et al., 2012) with state of knowledge ranked as low (1 out of 5). Several studies have ventured to answer these questions, tracking plant wax molecules through catchments, including in the Amazon River, the largest river drainage network in the world. From an elevation transect in the wet, forested, mountain sector of the Madre de Dios, Perú, an earlier study reported the $\delta \mathrm{D}$ values of plant wax $n$ alkanoic acids showing spatial averaging (Ponton et al., 2014). That finding is corroborated here, and further we find similar patterns of plant wax integration using both $\delta^{13} \mathrm{C}$ and $\delta \mathrm{D}$, analyzed in both the $n$-alkanoic acids and $n$-alkanes. In the lowland Amazon River network, Häggi et al. (2016) identified signals from the western basin as well as each of the tributaries contributing to the mainstem of the Amazon River, confirming the concept of spatial integration much further downstream for the $n$-alkanes.

If uniform spatial integration is a reasonable approximation for plant wax sourcing, in many catchments that means a lowland-dominated record based on areal extent, for example $c .90 \%$ of the Amazon Basin is lowland. River floodplains further appear to reset the transported plant wax signal to lowland values, not only because of additive inputs from greater lowland areal extent, but also because of degradation of the upland material in transit across floodplains (Galy et al., 2011; Häggi et al., 2016) or estuaries (Medeiros et al., 2012). Here, we find the concentrations of 
plant wax $n$-alkanes in river suspended sediments ( $\Sigma_{\text {alk }}$ and $\Lambda_{\text {alk }}$, Appendix A) remain relatively constant downstream despite increased catchment area, indicating degradation and replacement, rather than accumulation. Evidence for floodplain replacement also comes from the GangesBrahmaputra River network, where Galy et al. (2011) analyzed the $\delta^{13} \mathrm{C}$ and $\delta \mathrm{D}$ values of plant wax $n$-alkanoic acids in suspended sediment, finding differences between mountain-front tributaries, but ultimately showing a lowland signal upon export to the ocean.

Although steep terrain enables sedimentary erosion, the aforementioned studies have shown that such regions are unlikely to dominate plant wax sedimentary records, except when sampling in proximal locations. At mountain-front locations, there may be time-variable inputs associated with changing flow induced by storms and seasonal climate regimes (Clark et al., 2013), and by low frequency, large magnitude landslide events (Clark et al., 2016). For example, in the mountain-front river sampling of the Madre de Dios, seasonal Andean export and episodic storm inputs perturb the river suspended plant wax signal (Ponton et al., 2014).

While the Madre de Dios catchment is fully forested, other catchments include regions with sparse vegetation that yield little plant wax, e.g. the Tibetan portion of the Arun River catchment in Nepal (Hoffmann et al., 2016). Such regions are underrepresented in the exported plant wax signal relative to their spatial extent. However, various studies reveal that it is the soil stocks of plant waxes and not modern plant wax productivity that is critical to determining uneven contributions. From this Madre de Dios transect, $n$-alkane productivity in modern forests (Feakins et al., 2016a), together with $n$-alkane concentrations and $\delta^{13} \mathrm{C}$ signals in soils and rivers (this study) and analogous data for lignin (Feng et al., 2016), indicate that soil stocks are the major source of plant biomarkers to rivers (i.e. plant-to-soil-to-river), rather than direct from plant-to-river. Other studies find that this soil-to-river pathway is accentuated for those rivers 
that travel through regions with abundant stored sedimentary material. The Yellow River drains the loess plateau, and Tao et al. (2015) used compound-specific radiocarbon to establish that a large fraction of the exported plant wax was eroded from storage with an age of $\sim 1000$ years for the $n$-alkanoic acids and $>26,000$ years for the $n$-alkanes, in the extreme case of the loess storage. Some lowland tropical basins (including the Congo and Amazon) contain vast swamp areas, and these regions may at times be sinks or sources that contribute to the exported biomarker signal (Hemingway et al., 2016; Wagner et al., 2014). As river meanders migrate, they erode sedimentary deposits, likely remobilizing older plant wax (Torres et al., 2017), such as from Holocene peats (Householder et al., 2012) and Pleistocene age river terraces (Rigsby et al., 2009) in the Madre de Dios River basin.

We summarize these observations of plant waxes in transit in this and varied modern systems in Fig. 6 with a view to interpreting plant wax studies of paleoclimate and paleoenvironment. Broadly, uniform spatial averaging is a fair approximation for plant wax sourcing in many environments. Mountain lakes will necessarily receive a local signal. Mountain-front sedimentary deposits may record a variable signal, but lowlands will dominate the exported signal in most catchments because of their areal basis and ability to degrade upland organic matter and replace with lowland organic matter inputs, as well as their proximity to sedimentary sinks. Uniform averaging can be disrupted if a river erodes thick sedimentary sources that effectively 'over contribute'. Conversely, when the river erodes land that may be barren (or have low amounts) of vegetation and soil those areas may 'under contribute' based on their areal extent.

A contribution from this study is that both carbon and hydrogen isotopes can reveal remarkably consistent stories about catchment sourcing, in both the alkane and alkanoic acid compound 
classes. One interpretation could then be that either isotope system or compound class can be used to track sourcing. However, single isotope approaches in other settings may find that one or other of the isotope systems may be biased. For example, lowland aridity may shift the carbon isotopic composition to more positive values such that the altitude trend is diminished, or may shift the values at high elevation, such that the trend is accentuated. Or, lowland vegetation may include $\mathrm{C}_{4}$ grasses, and this would counteract the altitude trend. Alternatively, hydroclimate changes can alter the pattern of precipitation isotopes. In such cases the direction of divergence between the two isotope systems may reveal the explanation. In submarine fans, containing ancient river-transported sediments, several studies have shown that the dual isotope approach can be insightful about climate and vegetation (Hein et al., 2017; Schefuss et al., 2011; Schefuss et al., 2005). Although spatial patterns may remain obscure from single marine core reconstructions, the purpose of catchment sourcing studies is to reveal the source region integrated in river-transported sediments, even though sourcing may change over time. A powerful solution can be the study of multiple sedimentary deposits across catchments, to reveal the spatial distribution of changes on the landscape, e.g. the combination of terrestrial (Siwaliks) and marine (Bengal Fan) records (Freeman and Colarusso, 2001), or the comparison of the nested catchments of the Congo Fan (Schefuss et al., 2005) and Lake Tanganyika records (Tierney et al., 2008), reported in Sachse et al. (2012). 


\subsubsection{Potential for dual isotope plant wax paleoaltimetry}

Reconstructing the past elevation of landscapes is of interest for understanding tectonic processes (Garzione, 2008), climate dynamics (Molnar et al., 2010) and biological evolution (Antonelli et al., 2009; Hoorn et al., 2010). Many proxies for paleoelevation make use of the stable isotope gradient in meteoric water with elevation, as recorded in the $\delta^{18} \mathrm{O}$ value of carbonates (Blisniuk and Stern, 2005; Rowley, 2007). More recently, it has been noticed that plant wax organic matter archives the altitudinal gradient in the $\delta \mathrm{D}$ value of meteoric waters in soils (Bai et al., 2011; Jia et al., 2008; Luo et al., 2011; Ponton et al., 2014) and based on such observations, the $\delta \mathrm{D}_{\text {wax }}$ value has been used as a paleoaltimetry proxy on the Tibetan Plateau, on the Andean Altiplano and in the New Zealand Alps (Kar et al., 2016; Polissar et al., 2009; Zhuang et al., 2014; Zhuang et al., 2015). Our results provide additional evidence to support the use of hydrogen isotopes in plant wax as a paleoaltimetry proxy in ancient soils and fluvial deposits; further we introduce the concept of dual $\mathrm{C}$ and $\mathrm{H}$ isotopes in the same plant wax molecules for paleoaltimetry.

Altitude effects empirically determined in both the hydrogen and carbon isotopic composition of the forest canopy (Feakins et al., 2016a; Wu et al., 2017) are transferred to soils (Fig. 2) and to river sediments (Fig. 3), in two compound classes of leaf wax biomarkers ( $n$-alkanes and $n$ alkanoic acids). In theory river sediments carry altitudinal information, although these would reconstruct the catchment integrated elevation rather than being an in situ estimate, making paleosols the simpler case. Based on the relationship observed in soil M horizons (the major stock) across the elevation transect in the Madre de Dios basin (Fig. 2), we predict the isotopic signal that would be anticipated in paleosol samples with uplift from 2 to $4 \mathrm{~km}$ asl, together with uncertainties solely from the $\mathrm{M}$ horizon soil regression with elevation (Table 1). We also illustrate the elevation of all soil data (including $\mathrm{O}$ and $\mathrm{M}$ horizons) in dual isotope space, 
illustrating the power to differentiate sites separated in elevation by $0.5-1 \mathrm{~km}$ but no finer (Fig. 7), which provides a guide to paleoaltimetry potential.

Additional uncertainties exist, beyond that captured in the modern soil survey. For plant wax $\delta \mathrm{D}$ the principal uncertainty is usually the choice of the appropriate net fractionation factor between source water and plant wax needed to evaluate the isotopic composition of past precipitation. Net fractionations vary between plant type and climatic regime, but the largest shift in the net fractionation is typically seen when transitioning to grasslands which have larger $\mathrm{D} / \mathrm{H}$ fractionations than other lifeforms. A second concern surrounds aridity. Although plants can regulate water loss by their stomata, net carbon and hydrogen fractionations are generally smaller in drier environments than wet environments (Diefendorf et al., 2010; Feakins and Sessions, 2010; Sachse et al., 2012; Wei and Jia, 2009). Both plant type and climatic change likely accompany uplift, and such changes would alter the response in the plant wax archive from that seen in this forested, very wet altitude transect today.

Overall, the major concern with stable isotope approaches to paleoaltimetry is that uplift often engenders drying, such as is the case in the Andean Altiplano or Tibetan Plateau, and this drying affects stable isotope based altimetry as recorded in carbonates (Rowley and Garzione, 2007). The plant wax proxy should be less sensitive to aridity as transpiration losses from plants are restricted unlike evaporative losses affecting carbonates. Further the plant wax archive is uniquely suited to monitor for the confounding effect of aridity, because of the ability to measure both stable $\mathrm{C}$ and $\mathrm{H}$ isotopes in the same molecule. We find a negative correlation between $\delta \mathrm{D}$ and $\delta^{13} \mathrm{C}$ values across the elevation transect in the ever-wet scenario studied here (Fig. 4), whereas drying would be expected to lead to a positive correlation between $\delta \mathrm{D}$ and $\delta^{13} \mathrm{C}$. The 
combination of plant wax carbon and hydrogen isotopic analyses in the same molecules therefore provides a check on hydrological changes that may compromise either altimeter. Thus, for paleoaltimetry applications of the plant wax paleoprecipitation proxy, we recommend dual analysis of $\mathrm{C}$ and $\mathrm{H}$, spanning time in an ancient deposit, or ideally a series of deposits across a topographic feature, to discriminate between a past scenario with a) high $\delta^{13} \mathrm{C}_{\mathrm{wax}}$ and low $\delta \mathrm{D}_{\text {wax }}$ that would be interpreted as higher elevation than modern or b) high $\delta^{13} \mathrm{C}_{\mathrm{wax}}$ and high $\delta \mathrm{D}_{\text {wax }}$ that would be interpreted as drier than modern. Past vegetation change would ideally be also monitored (e.g., using plant wax chain length distributions, pollen or macrofossil analyses), and we suggest such concerns about plant type bias would be greater in soils or different facies than in broadly integrated deposits that average plant inputs. In this way we hope that the dual-isotope information from plant waxes can usefully add additional monitoring and diagnostic power to efforts at paleoaltimetry with $\delta \mathrm{D}_{\text {wax }}$. This dual isotope plant wax proxy may be a welcome addition to the available toolkit for paleoaltimetry including carbonate and other secondary mineral archives of precipitation oxygen isotopes (Poage and Chamberlain, 2002), clumped isotope estimates of temperature (Huntington et al., 2010), and microbial proxies for temperature (Peterse et al., 2009), each may variously find application in different sedimentary archives and contribute to multi-proxy efforts to robustly determine paleoelevation in the Andes and elsewhere. 


\section{Conclusions}

This study takes a dual compound class and dual isotope approach to survey plant waxes in soils and river sediments in a transect across the eastern flank of the Andes in a forested, steep, very wet, tropical mountain watershed. We observe elevation trends in both $\mathrm{C}$ and $\mathrm{H}$ isotopes and $n$ alkane and $n$-alkanoic acid compound classes stored in soils and transported in fluvial suspended sediments. The altitudinal trend in the $\mathrm{C}$ and $\mathrm{H}$ isotopic composition of plant wax hydrocarbons represents a powerful diagnostic tool for tracking elevation in catchment sourcing studies, and offers potential for paleoaltimetry.

In river transported sediments, we test whether sedimentary integration is uniform or whether steep regions with high sedimentary erosion rates lead to bias in the plant wax sedimentary record. In our field collection we find plant wax concentrations and suspended sediment concentrations are very low in the dry season in the upper reaches, and that most of the erosion occurs in the wet season. Comparing the empirical regression from the transect of soil plots to the river exported signal based on the catchment mean elevation, the slope of the regression is shallower in the rivers implying that the upland sources are under-represented, but this is not robust to the uncertainty on the regression and the implications are in any case erased by the expansive lowlands where uniform spatial integration is a good approximation. Uplands are never over-represented, but their export occurs primarily during the more erosive wet season, and in the dry season the locus of erosion reduces by at least $1 \mathrm{~km}$ at the mountain front station, with less seasonality seen further downstream. Within deep rivers, we observe modest depth differentiation for the carbon isotopic composition of the $n$-alkanes with more degraded components derived from weathered soils in the upper water column, but no depth differentiation for the other isotopes studied here. 
We introduce the concept of a dual isotope approach for plant wax studies as a diagnostic tool to discern source characteristics other than elevation signals in some river samples. The strong elevation signal in this study is confirmed through this approach and indicates the power in combining dual compound classes and dual isotopes to analyze source-to-sink processes for plant wax biomarkers. Overall, the large lowland area of many river catchments means that upland sources of plant wax will become negligible in many distal archives, and the lowland floodplains are thus important for the replacement of the fluvially-exported plant wax component. 


\section{Author Contribution Statement}

A.J.W. and S.J.F designed the study. A.J.W., S.J.F, V.G and C.P. conducted the river sampling. C.P. and M.S.W conducted laboratory work and S.F. guided analytical work and interpretations. M.S.W. measured leaf wax carbon and hydrogen isotope analyses and graphed the results. S.J.F. wrote the manuscript. All authors contributed to this study.

\section{Acknowledgements}

This material is based upon work supported by the US National Science Foundation under Grant No. EAR-1227192 to A.J.W and S.J.F for the river work. In Perú, we thank the Servicio Nacional de Áreas Naturales Protegidas por el Estado (SERNANP) and personnel of Manu and Tambopata National Parks for logistical assistance and permission to work in the protected areas. We thank the Explorers' Inn and the Pontifical Catholic University of Perú (PUCP), as well as Amazon Conservation Association for use of the Tambopata and Wayqecha Research Stations, respectively. For river fieldwork assistance, we thank M. Torres, A. Robles and A. Ccahuana. Soil samples were contributed by Andrew Nottingham and Patrick Meir. Logistical support was provided by Y. Malhi, J. Huaman, W. Huaraca Huasco and other collaborators as part of the Andes Biodiversity and Ecosystems Research Group ABERG (andesresearch.org). We thank USC lab assistants: C. Hua, K. McPherson and E. Rosca. We thank B. Bookhagen, J. Polk, G. Li, K. Clark, G. Asner, Y. Malhi and X. Feng for helpful discussions. This manuscript was revised with comments from Associate Editor Tom Wagner, reviewer Clay Magill and two anonymous reviewers.

\section{Supplementary Information}


Supplementary data associated with this article can be found, in the online version, at http...

These data include Google maps of the most important areas described in this article.

\section{References}

Antonelli, A., Nylander, J.A.A., Persson, C. and Sanmartin, I. (2009) Tracing the impact of the Andean uplift on Neotropical plant evolution. Proc. Natl. Acad. Sci. U. S. A. 106, 97499754.

Asner, G.P. and Martin, R.E. (2016) Convergent elevation trends in canopy chemical traits of tropical forests. Glob. Change Biol. 22, 2216-2227.

Asner, G.P., Martin, R.E., Tupayachi, R., Anderson, C.B., Sinca, F., Carranza-Jiménez, L. and Martinez, P. (2014) Amazonian functional diversity from forest canopy chemical assembly. Proc. Natl. Acad. Sci. U. S. A. 111, 5604-5609.

Aufdenkampe, A.K., Mayorga, E., Hedges, J.I., Llerena, C., Quay, P.D., Gudeman, J., Krusche, A.V. and Richey, J.E. (2007) Organic matter in the Peruvian headwaters of the Amazon: Compositional evolution from the Andes to the lowland Amazon mainstem. Org. Geochem. 38, 337-364.

Bai, Y., Fang, X.M., Gleixner, G. and Mugler, I. (2011) Effect of precipitation regime on delta D values of soil n-alkanes from elevation gradients - Implications for the study of paleoelevation. Org. Geochem. 42, 838-845.

Bendle, J.A., Weijers, J.W.H., Maslin, M.A., Sinninghe Damsté, J.S., Schouten, S., Hopmans, E.C., Boot, C.S. and Pancost, R.D. (2010) Major changes in glacial and Holocene terrestrial temperatures and sources of organic carbon recorded in the Amazon fan by tetraether lipids. Geochem. Geophys. Geosyst. 11, Q12007.

Beusen, A.H.W., Dekkers, A.L.M., Bouwman, A.F., Ludwig, W. and Harrison, J. (2005) Estimation of global river transport of sediments and associated particulate $\mathrm{C}, \mathrm{N}$, and $\mathrm{P}$. Glob. Biogeochem. Cycle 19, doi:10.1029/2005GB002453.

Blisniuk, P.M. and Stern, L.A. (2005) Stable isotope paleoaltimetry: A critical review. Am. J. Sci. 305, 1033-1074.

Bouchez, J., Galy, V., Hilton, R.G., Gaillardet, J., Moreira-Turcq, P., Pérez, M.A., FranceLanord, C. and Maurice, L. (2014) Source, transport and fluxes of Amazon River particulate organic carbon: Insights from river sediment depth-profiles. Geochim. Cosmochim. Acta 133, 280-298.

Chikaraishi, Y., Yamada, Y. and Naraoka, H. (2005) Carbon and hydrogen isotopic compositions of sterols from riverine and marine sediments. Limnol. Oceanogr. 50, 17631770 .

Clark, K.E., Hilton, R.G., West, A.J., Malhi, Y., Grocke, D.R., Bryant, C.L., Ascough, P.L., Robles C, A. and New, M. (2013) New views on 'old' carbon in the Amazon river: Insight from the source of organic carbon eroded from the Peruvian Andes. Geochem. Geophys. Geosyst., doi: 10.1002/ggge.20122.

Clark, K.E., Hilton, R.G., West, A.J., Robles Caceres, A., Gröcke, D.R., Marthews, T.R., Ferguson, R.I., Asner, G.P., New, M. and Malhi, Y. (2017) Erosion of organic carbon from the Andes and its effects on ecosystem carbon dioxide balance. J. Geophys. ResBiogeo. 122, 449-469. 
Clark, K.E., West, A.J., Hilton, R.G., Asner, G.P., Quesada, C.A., Silman, M.R., Saatchi, S.S., Farfan-Rios, W., Martin, R.E., Horwath, A.B., Halladay, K., New, M. and Malhi, Y.

(2016) Storm-triggered landslides in the Peruvian Andes and implications for topography, carbon cycles, and biodiversity. Earth Surf. Dynam. 4, 47-70.

Cole, J.J., Prairie, Y.T., Caraco, N.F., McDowell, W.H., Tranvik, L.J., Striegl, R.G., Duarte, C.M., Kortelainen, P., Downing, J.A., Middelburg, J.J. and Melack, J. (2007) Plumbing the Global Carbon Cycle: Integrating Inland Waters into the Terrestrial Carbon Budget. Ecosystems 10, 172-185.

Diefendorf, A.F. and Freimuth, E.J. (2017) Extracting the most from terrestrial plant-derived nalkyl lipids and their carbon isotopes from the sedimentary record: A review. Org. Geochem. 103, 1-21.

Diefendorf, A.F., Mueller, K.E., Wing, S.L., Koch, P.L. and Freeman, K.H. (2010) Global patterns in leaf ${ }^{13} \mathrm{C}$ discrimination and implications for studies of past and future climate. Proc. Natl. Acad. Sci. U. S. A. 107, 5738-5743.

Eglinton, T.I. and Eglinton, G. (2008) Molecular proxies for paleoclimatology. Earth Planet. Sci. Lett. 275, 1-16.

Feakins, S.J. and Sessions, A.L. (2010) Controls on the D/H ratios of plant leaf waxes from an arid ecosystem. Geochim. Cosmochim. Acta 74, 2128-2141.

Feakins, S.J., Bentley, L.P., Salinas, N., Shenkin, A., Blonder, B., Goldsmith, G.R., Ponton, C., Arvin, L.J., Wu, M.S., Peters, T., West, A.J., Martin, R.E., Enquist, B.J., Asner, G.P. and Malhi, Y. (2016a) Plant leaf wax biomarkers capture gradients in hydrogen isotopes of precipitation from the Andes and Amazon. Geochim. Cosmochim. Acta 182, 155-172.

Feakins, S.J., Levin, N., Liddy, H., Sieracki, A., Eglinton, T. and Bonnefille, R. (2013) Northeast African vegetation change over 12 million years. Geology 41, 295-298.

Feakins, S.J., Peters, T., Wu, M.S., Shenkin, A., Salinas, N., Girardin, C.A.J., Bentley, L.P., Blonder, B., Enquist, B.J., Martin, R.E., Asner, G.P. and Malhi, Y. (2016b) Production of leaf wax n-alkanes across a tropical forest elevation transect. Org. Geochem. 100, 89-100.

Feng, X., Feakins, S.J., Liu, Z., Ponton, C., Wang, R.Z., Karkabi, E., Galy, V., Berelson, W.M., Nottingham, A.T., Meir, P. and West, A.J. (2016) Source to sink: Evolution of lignin composition in the Madre de Dios River system with connection to the Amazon basin and offshore. J. Geophys. Res-Biogeo. 121, 1316-1338.

France-Lanord, C. and Derry, L.A. (1997) Organic carbon burial forcing of the carbon cycle from Himalayan erosion. Nature 390, 65-67.

Freeman, K.H. and Colarusso, L.A. (2001) Molecular and isotopic records of $\mathrm{C}_{4}$ grassland expansion in the late Miocene. Geochim. Cosmochim. Acta 65, 1439-1454.

Freymond, C.V., Kündig, N., Stark, C., Peterse, F., Buggle, B., Lupker, M., Plötze, M., Blattmann, T.M., Filip, F., Giosan, L. and Eglinton, T.I. (2018) Evolution of biomolecular loadings along a major river system. Geochim. Cosmochim. Acta 223, 389404.

Friedli, H., Lotscher, H., Oeschger, H., Siegenthaler, U. and Stauffer, B. (1986) Ice core record of the C-13/C-12 ratio of atmospheric $\mathrm{CO}_{2}$ in the past 2 Centuries. Nature 324, 237-238.

Galy, V. and Eglinton, T. (2011) Protracted storage of biospheric carbon in the GangesBrahmaputra basin. Nature Geosci. 4, 843-847.

Galy, V., Eglinton, T., France-Lanord, C. and Sylva, S. (2011) The provenance of vegetation and environmental signatures encoded in vascular plant biomarkers carried by the GangesBrahmaputra rivers. Earth Planet. Sci. Lett. 304, 1-12. 
Galy, V., France-Lanord, C., Beyssac, O., Faure, P., Kudrass, H. and Palhol, F. (2007) Efficient organic carbon burial in the Bengal fan sustained by the Himalayan erosional system. Nature 450, 407-U406.

Galy, V., Peucker-Ehrenbrink, B. and Eglinton, T. (2015) Global carbon export from the terrestrial biosphere controlled by erosion. Nature 521, 204-207.

Garzione, C.N. (2008) Rise of the Andes (vol 320,pg 1304, 2008). Science 321, 1295-1295.

Girardin, C.A.J., Aragão, L.E.O.C., Malhi, Y., Huaraca Huasco, W., Metcalfe, D.B., Durand, L., Mamani, M., Silva-Espejo, J.E. and Whittaker, R.J. (2013) Fine root dynamics along an elevational gradient in tropical Amazonian and Andean forests. Glob. Biogeochem. Cycle 27, 252-264.

Giri, S.J., Diefendorf, A.F. and Lowell, T.V. (2015) Origin and sedimentary fate of plant-derived terpenoids in a small river catchment and implications for terpenoids as quantitative paleovegetation proxies. Org. Geochem. 82, 22-32.

Goñi, M.A., Yunker, M.B., Macdonald, R.W. and Eglinton, T.I. (2000) Distribution and sources of organic biomarkers in arctic sediments from the Mackenzie River and Beaufort Shelf. Mar. Chem. 71, 23-51.

Häggi, C., Sawakuchi, A.O., Chiessi, C.M., Mulitza, S., Mollenhauer, G., Sawakuchi, H.O., Baker, P.A., Zabel, M. and Schefuß, E. (2016) Origin, transport and deposition of leafwax biomarkers in the Amazon Basin and the adjacent Atlantic. Geochim. Cosmochim. Acta 192, 149-165.

Halladay, K., Malhi, Y. and New, M. (2012) Cloud frequency climatology at the Andes/Amazon transition: 1. Seasonal and diurnal cycles. J. Geophys. Res-Atmos. 117, D23102.

Hanna, A.J.M., Shanahan, T.M. and Allison, M.A. (2016) Distribution of branched GDGTs in surface sediments from the Colville River, Alaska: Implications for the $\mathrm{MBT}^{\prime} / \mathrm{CBT}$ paleothermometer in Arctic marine sediments. J. Geophys. Res-Biogeo, doi:10.1002/2015JG003266.

Hedges, J.I., Mayorga, E., Tsamakis, E., McClain, M.E., Aufdenkampe, A., Quay, P., Richey, J.E., Benner, R., Opsahl, S., Black, B., Pimentel, T., Quintanilla, J. and Maurice, L. (2000) Organic matter in Bolivian tributaries of the Amazon River: A comparison to the lower mainstream. Limnol. Oceanogr. 45, 1449-1466.

Hedges, J.I. and Oades, J.M. (1997) Comparative organic geochemistries of soils and marine sediments. Org. Geochem. 27, 319-361.

Hein, C.J., Galy, V., Galy, A., France-Lanord, C., Kudrass, H. and Schwenk, T. (2017) Postglacial climate forcing of surface processes in the Ganges-Brahmaputra river basin and implications for carbon sequestration. Earth Planet. Sci. Lett. 478, 89-101.

Hemingway, J.D., Schefuß, E., Dinga, B.J., Pryer, H. and Galy, V.V. (2016) Multiple plant-wax compounds record differential sources and ecosystem structure in large river catchments. Geochim. Cosmochim. Acta 184, 20-40.

Hemingway, J.D., Schefuß, E., Spencer, R.G.M., Dinga, B.J., Eglinton, T.I., McIntyre, C. and Galy, V.V. (2017) Hydrologic controls on seasonal and inter-annual variability of Congo River particulate organic matter source and reservoir age. Chem. Geol. 466, 454-465.

Hoffmann, B., Feakins, S.J., Bookhagen, B., Olen, S.M., Adhikari, D.P., Mainali, J. and Sachse, D. (2016) Climatic and geomorphic drivers of plant organic matter transport in the Arun River, E Nepal. Earth Planet. Sci. Lett. 452, 104-114.

Hoorn, C., Wesselingh, F.P., ter Steege, H., Bermudez, M.A., Mora, A., Sevink, J., Sanmartin, I., Sanchez-Meseguer, A., Anderson, C.L., Figueiredo, J.P., Jaramillo, C., Riff, D., Negri, 
F.R., Hooghiemstra, H., Lundberg, J., Stadler, T., Sarkinen, T. and Antonelli, A. (2010) Amazonia Through Time: Andean Uplift, Climate Change, Landscape Evolution, and Biodiversity. Science 330, 927-931.

Householder, J.E., Janovec, J.P., Tobler, M.W., Page, S. and Lahteenoja, O. (2012) Peatlands of the Madre de Dios River of Peru: Distribution, Geomorphology, and Habitat Diversity. Wetlands 32, 359-368.

Huntington, K.W., Wernicke, B.P. and Eiler, J.M. (2010) Influence of climate change and uplift on Colorado Plateau paleotemperatures from carbonate clumped isotope thermometry. Tectonics 29, doi:10.1029/2009TC002449.

Jarvis, A., Reuter, H., Nelson, A. and Guevara, E. (2008) Hole-filled seamless SRTM data V4, International Centre for Tropical Agriculture (CIAT). url: http://srtm.csi.cgiar.org.

Jia, G.D., Wei, K., Chen, F.J. and Peng, P.A. (2008) Soil n-alkane delta D vs. altitude gradients along Mount Gongga, China. Geochim. Cosmochim. Acta 72, 5165-5174.

Kar, N., Garzione, C.N., Jaramillo, C., Shanahan, T., Carlotto, V., Pullen, A., Moreno, F., Anderson, V., Moreno, E. and Eiler, J. (2016) Rapid regional surface uplift of the northern Altiplano plateau revealed by multiproxy paleoclimate reconstruction. Earth Planet. Sci. Lett. 447, 33-47.

Killeen, T.J., Douglas, M., Consiglio, T., Jørgensen, P.M. and Mejia, J. (2007) Dry spots and wet spots in the Andean hotspot. J. Biogeog. 34, 1357-1373.

Kim, J.H., Zell, C., Moreira-Turcq, P., Perez, M.A.P., Abril, G., Mortillaro, J.M., Weijers, J.W.H., Meziane, T. and Damste, J.S.S. (2012) Tracing soil organic carbon in the lower Amazon River and its tributaries using GDGT distributions and bulk organic matter properties. Geochim. Cosmochim. Acta 90, 163-180.

Körner, C., Farquhar, G.D. and Roksandic, Z. (1988) A global survey of carbon isotope discrimination in plants from high altitude. Oecologia 74, 623-632.

Koven, C.D., Hugelius, G., Lawrence, D.M. and Wieder, W.R. (2017) Higher climatological temperature sensitivity of soil carbon in cold than warm climates. Nature Clim. Change 7, $817-822$.

Kusch, S., Rethemeyer, J., Schefuß, E. and Mollenhauer, G. (2010) Controls on the age of vascular plant biomarkers in Black Sea sediments. Geochim. Cosmochim. Acta 74, 70317047.

Lee, H., Feakins, S.J., Lu, Z., Schimmelmann, A., Sessions, A.L., Tierney, J.E. and Williams, T.J. (2017) Comparison of three methods for the methylation of aliphatic and aromatic compounds. Rapid Commun. Mass Spectrom. 31, 1633-1640.

Luo, P., Peng, P.A., Gleixner, G., Zheng, Z., Pang, Z.H. and Ding, Z.L. (2011) Empirical relationship between leaf wax $n$-alkane delta $\mathrm{D}$ and altitude in the Wuyi, Shennongjia and Tianshan Mountains, China: Implications for paleoaltimetry. Earth Planet. Sci. Lett. 301, 285-296.

Marseille, F., Disnar, J.R., Guillet, B. and Noack, Y. (1999) $n$-alkanes and free fatty acids in humus and $\mathrm{Al}$ horizons of soils under beech, spruce and grass in the Massif-Central (Mont-Lozere), France. Eur. J. Soil Sci. 50, 433-441.

Mayorga, E., Aufdenkampe, A.K., Masiello, C.A., Krusche, A.V., Hedges, J.I., Quay, P.D., Richey, J.E. and Brown, T.A. (2005) Young organic matter as a source of carbon dioxide outgassing from Amazonian rivers. Nature 436, 538-541. 
Meade, R., Dunne, T., Richey, J., De M. Santos, U. and Salati, E. (1985) Storage and Remobilization of Suspended Sediment in the Lower Amazon River of Brazil. Science 228, 488-490.

Medeiros, P.M., Sikes, E.L., Thomas, B. and Freeman, K.H. (2012) Flow discharge influences on input and transport of particulate and sedimentary organic carbon along a small temperate river. Geochim. Cosmochim. Acta 77, 317-334.

Meybeck, M. and Ragu, A. (2012) GEMS-GLORI world river discharge database. PANGAEA.

Molnar, P., Boos, W.R. and Battisti, D.S. (2010) Orographic Controls on Climate and Paleoclimate of Asia: Thermal and Mechanical Roles for the Tibetan Plateau, Ann. Rev. Earth Planet. Sci., 38, 77-102.

Nguyen Tu, T.T., Derenne, S., Largeau, C., Bardoux, G. and Mariotti, A. (2004) Diagenesis effects on specific carbon isotope composition of plant $n$-alkanes. Org. Geochem. 35, 317-329.

Niedermeyer, E.M., Sessions, A.L., Feakins, S.J. and Mohtadi, M. (2014) Hydroclimate of the western Indo-Pacific Warm Pool during the past 24,000 years. Proc. Natl. Acad. Sci. U. S. A. 111, 9402-9406.

Pagani, M., Pedentchouk, N., Huber, M., Sluijs, A., Schouten, S., Brinkhuis, H., Damste, J.S.S. and Dickens, G.R. (2006) Arctic hydrology during global warming at the Palaeocene/Eocene thermal maximum. Nature 442, 671-675.

Pearson, A. and Eglinton, T. (2000) The origin of n-alkanes in Santa Monica Basin surface sediment: a model based on compound-specific $\Delta^{14} \mathrm{C}$ and $\delta^{13} \mathrm{C}$ data. Org. Geochem. 31, 1103-1116.

Peterse, F., van der Meer, M.T.J., Schouten, S., Jia, G., Ossebaar, J., Blokker, J. and Damste, J.S.S. (2009) Assessment of soil $n$-alkane delta D and branched tetraether membrane lipid distributions as tools for paleoelevation reconstruction. Biogeosci. 6, 2799-2807.

Poage, M.A. and Chamberlain, C.P. (2001) Empirical relationships between elevation and the stable isotope composition of precipitation and surface waters: Considerations for studies of paleoelevation change. Am. J. Sci. 201, 1-15.

Polissar, P.J., Freeman, K.H., Rowley, D.B., McInerney, F.A. and Currie, B.S. (2009) Paleoaltimetry of the Tibetan Plateau from D/H ratios of lipid biomarkers. Earth Planet. Sci. Lett. 287, 64-76.

Ponton, C., West, A.J., Feakins, S.J. and Galy, V. (2014) Leaf wax biomarkers in transit record river catchment composition. Geophys. Res. Lett. 41, 6420-6427.

Rasse, D.P., Rumpel, C. and Dignac, M.-F. (2005) Is soil carbon mostly root carbon? Mechanisms for a specific stabilisation. Plant Soil 269, 341-356.

Richey, J.E., Hedges, J.I., Devol, A.H., Quay, P.D., Victoria, R., Martinelli, L. and Forsberg, B.R. (1990) Biogeochemistry of carbon in the Amazon River. Limnol. Oceanogr. 35, $352-371$.

Richey, J.E., Melack, J.M., Aufdenkampe, A.K., Ballester, V.M. and Hess, L.L. (2002) Outgassing from Amazonian rivers and wetlands as a large tropical source of atmospheric $\mathrm{CO}_{2}$. Nature 416, 617-620.

Rigsby, C.A., Hemric, E.M. and Baker, P.A. (2009) Late Quaternary Paleohydrology of the Madre de Dios River, southwestern Amazon Basin, Peru. Geomorphology 113, 158-172.

Rowley, D.B. (2007) Stable isotope-based paleoaltimetry: Theory and validation. Rev. Mineral. Geochem. 66, 23-52. 
Rowley, D.B. and Garzione, C.N. (2007) Stable Isotope-Based Paleoaltimetry. Ann. Rev. Earth Planet. Sci. 35, 463-508.

Sachse, D., Billault, I., Bowen, G.J., Chikaraishi, Y., Dawson, T.E., Feakins, S.J., Freeman, K.H., Magill, C.R., McInerney, F.A., van der Meer, M.T.J., Polissar, P., Robins, R.J., Sachs, J.P., Schmidt, H.-L., Sessions, A.L., White, J.W.C., West, J.B. and Kahmen, A. (2012) Molecular Paleohydrology: Interpreting the Hydrogen-Isotopic Composition of Lipid Biomarkers from Photosynthesizing Organisms. Ann. Rev. Earth Planet. Sci. 40, 221-249.

Schefuss, E., Kuhlmann, H., Mollenhauer, G., Prange, M. and Patzold, J. (2011) Forcing of wet phases in southeast Africa over the past 17,000 years. Nature 480, 509-512.

Schefuss, E., Schouten, S., Jansen, J.H.F. and Damste, J.S.S. (2003) African vegetation controlled by tropical sea surface temperatures in the mid-Pleistocene period. Nature $\mathbf{4 2 2}$, 418-421.

Schefuss, E., Schouten, S. and Schneider, R. (2005) Climatic controls on central African hydrology during the past 20,000 years. Nature 473, 1003-1006.

Schmidt, M.W.I., Torn, M.S., Abiven, S., Dittmar, T., Guggenberger, G., Janssens, I.A., Kleber, M., Kogel-Knabner, I., Lehmann, J., Manning, D.A.C., Nannipieri, P., Rasse, D.P., Weiner, S. and Trumbore, S.E. (2011) Persistence of soil organic matter as an ecosystem property. Nature 478, 49-56.

Tao, S.Q., Eglinton, T.I., Montlucon, D.B., McIntyre, C. and Zhao, M.X. (2015) Pre-aged soil organic carbon as a major component of the Yellow River suspended load: Regional significance and global relevance. Earth Planet. Sci. Lett. 414, 77-86.

Tierney, J.E., Russell, J.M., Huang, Y.S., Damste, J.S.S., Hopmans, E.C. and Cohen, A.S. (2008) Northern hemisphere controls on tropical southeast African climate during the past 60,000 years. Science 322, 252-255.

Torres, M. A., Limaye, A. B., Ganti, V., Lamb, M. P., West, A. J., and Fischer, W. W. (2017): Model predictions of long-lived storage of organic carbon in river deposits, Earth Surf. Dynam., 5, 711-730.

Townsend-Small, A., McClain, M.E. and Brandes, J.A. (2005) Contributions of carbon and nitrogen from the Andes Mountains to the Amazon River: Evidence from an elevational gradient of soils, plants, and river material. Limnol. Oceanogr. 50, 672-685.

Townsend-Small, A., McClain, M.E., Hall, B., Noguera, J.L., Llerena, C.A. and Brandes, J.A. (2008) Suspended sediments and organic matter in mountain headwaters of the Amazon River: Results from a 1-year time series study in the central Peruvian Andes. Geochim. Cosmochim. Acta 72, 732-740.

Townsend-Small, A., Noguera, J.L., McClain, M.E. and Brandes, J.A. (2007) Radiocarbon and stable isotope geochemistry of organic matter in the Amazon headwaters, Peruvian Andes. Glob. Biogeochem. Cycle 21, GB2029, doi:10.1029/2006GB002835.

Trumbore, S.E. (1993) Comparison of carbon dynamics in tropical and temperate soils using radiocarbon measurements. Glob. Biogeochem. Cycle 7, 275-290.

Wagner, T., Kallweit, W., Talbot, H.M., Mollenhauer, G., Boom, A. and Zabel, M. (2014) Microbial biomarkers support organic carbon transport from methane-rich Amazon wetlands to the shelf and deep sea fan during recent and glacial climate conditions. Org. Geochem. 67, 85-98.

Wiesenberg, G.L.B., Schwarzbauer, J., Schmidt, M.W.I. and Schwark, L. (2004) Source and turnover of organic matter in agricultural soils derived from $n$-alkane $/ n$-carboxylic acid compositions and C-isotope signatures. Org. Geochem. 35, 1371-1393. 
Wu, M.S., Feakins, S.J., Martin, R.E., Shenkin, A., Bentley, L.P., Blonder, B., Salinas, N., Asner, G.P. and Malhi, Y. (2017) Altitude effect on leaf wax carbon isotopic composition in humid tropical forests. Geochim. Cosmochim. Acta 206, 1-17.

Zhuang, G.S., Brandon, M.T., Pagani, M. and Krishnan, S. (2014) Leaf wax stable isotopes from Northern Tibetan Plateau: Implications for uplift and climate since $15 \mathrm{Ma}$. Earth Planet. Sci. Lett. 390, 186-198.

Zhuang, G.S., Pagani, M., Chamberlin, C., Strong, D. and Vandergoes, M. (2015) Altitudinal shift in stable hydrogen isotopes and microbial tetraether distribution in soils from the Southern Alps, NZ: Implications for paleoclimatology and paleoaltimetry. Org. Geochem. 79, 56-64. 


\section{Figure and Table Captions}

Fig. 1. Shaded relief map showing soil and river sampling locations in (a) the Madre de Dios River network and (b) the Kosñipata River which drains into the Madre de Dios River. River sample code prefix (wet season: CMD; dry season: MMD) is omitted on map. River sample codes are differentiated into wet (blue) or dry (red) season samples, mainstem (Kosñipata River and Madre de Dios river; no underline) or tributary samples (underlined), or stormflow samples (parentheses). Soil sample codes are in brown. Digital elevation model is derived from the 3 arcsecond (approx. 90 m) Shuttle Radar Topography Mission (SRTM) data (Jarvis et al., 2008).

Fig. 2. Soil isotopic gradients showing (a) $\delta^{13} \mathrm{C} \mathrm{C}_{29} n$-alkane, (b) $\delta^{13} \mathrm{C} \mathrm{C}_{30} n$-alkanoic acid, (c) $\delta \mathrm{D}$ $\mathrm{C}_{29} n$-alkane and (d) $\delta \mathrm{D} \mathrm{C}_{30} n$-alkanoic acid in soil $\mathrm{O}$ (violet) and $\mathrm{M}$ (orange) horizons, as well as canopy leaf site-means (green; $\delta^{13} \mathrm{C} \mathrm{Wu}$ et al., 2017, $\delta \mathrm{D}$ Feakins et al., 2016), showing $1 \sigma$ uncertainties (error bars), ordinary least squares (OLS) linear regressions (lines; all with $\mathrm{p}<0.0001)$ with regression uncertainties ( $1 \sigma$ : shading). No regression plotted for canopy leaves in $\mathrm{b}$ or $\mathrm{d}$ because the relationship is not significant, but this is thought to be a type II error, due to the insufficient number of sites along the transect $(n=5)$. Insets show the relationship between soil $\mathrm{O}$ and $\mathrm{M}$ horizons. Note that soil $\mathrm{O}$ horizon samples at sites TP3 and TP4 contain $<10 \%$ OC (open squares, included in the regression).

Fig. 3. River data (wet season: blue circle; dry season: red diamond) showing $\delta^{13} \mathrm{C}$ (top) and $\delta \mathrm{D}$ (bottom) of $\mathrm{C}_{29} n$-alkane (left) and $\mathrm{C}_{30} n$-alkanoic acid (right) from river suspended sediments (error bars: $1 \sigma$ uncertainties) from main stem (solid symbol) and tributary (open symbol). OLS linear regressions (blue lines) are shown for wet season samples with regression uncertainties ( $1 \sigma$ : shading). CMD 16 and 31 are outliers, with low CPI evidence for petrogenic contamination (crosses, not included in regression). Regressions for dry season samples are not significant 
(dashed line; $p>0.05$ ). Also showing data from depth profile samples (grey, not included in the regression).

Fig. 4. Properties of bulk sediment and plant wax biomarkers in the depth profiles of the Madre de Dios River: (a) sediment load, (b) organic carbon content (OC\%), (c) OC-normalized total $n$ alkane abundance $\left(\Lambda_{\text {alk }}\right)$, (d) carbon preference index of $\mathrm{C}_{27-33} n$-alkanes $\left(\mathrm{CPI}_{\text {alk }}\right)$, (e) specific surface area (SSA), (f) $\delta^{13} \mathrm{C}_{29 a 1 k}$, (g) $\delta^{13} \mathrm{C}_{30 \text { acid, }}$ (h) $\delta \mathrm{D}_{30 a c i d}$, (i) $\delta \mathrm{D}_{29 a 1 k}$.

Fig. 5. Comparison of $\delta \mathrm{D}$ and $\delta^{13} \mathrm{C}$ values of (a) $\mathrm{C}_{29} n$-alkane and (b) $\mathrm{C}_{30} n$-alkanoic acid for river suspended sediments in wet (blue circles) and dry (red diamonds) seasons, as well as the depth profile samples (grey). OLS linear regressions are shown for the river wet season and soil $\mathrm{O}$ (violet) and $\mathrm{M}$ (orange) horizons (individual data of soil is shown in Fig. 6) with $1 \sigma$ regression uncertainties (shading). CMD 31 is an outlier, with low CPI evidence for petroleum contamination.

Fig. 6. Synthesis of plant wax sedimentary integration studies (Galy et al., 2011; Häggi et al., 2016; Hemingway et al., 2016; Hoffmann et al., 2016; Ponton et al., 2014; Tao et al., 2015).

Fig. 7. Comparison of $\delta \mathrm{D}$ and $\delta^{13} \mathrm{C}$ values of (a) $\mathrm{C}_{29} n$-alkanes and (b) $\mathrm{C}_{30} n$-alkanoic acids in both the soil $\mathrm{O}$ and $\mathrm{M}$ horizon samples (undifferentiated). Symbol colors correspond to sampling elevation (see legend). Orthogonal distance regressions (black lines) are shown with $1 \sigma$ regression uncertainties (grey shading).

Table 1. Predicting paleoaltimetry using a dual isotope plant wax approach in paleosols. 
Figure 1
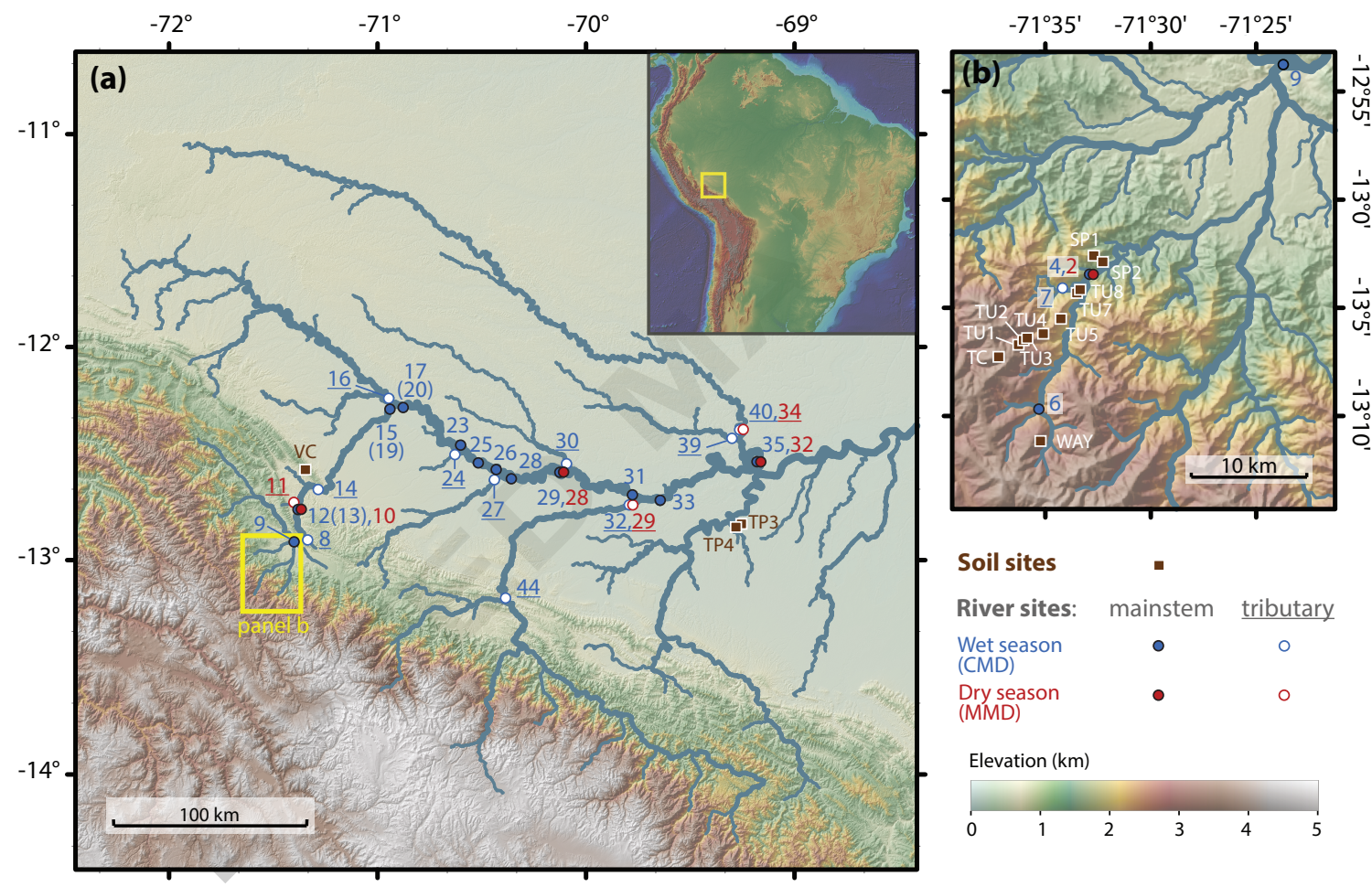
Figure 2
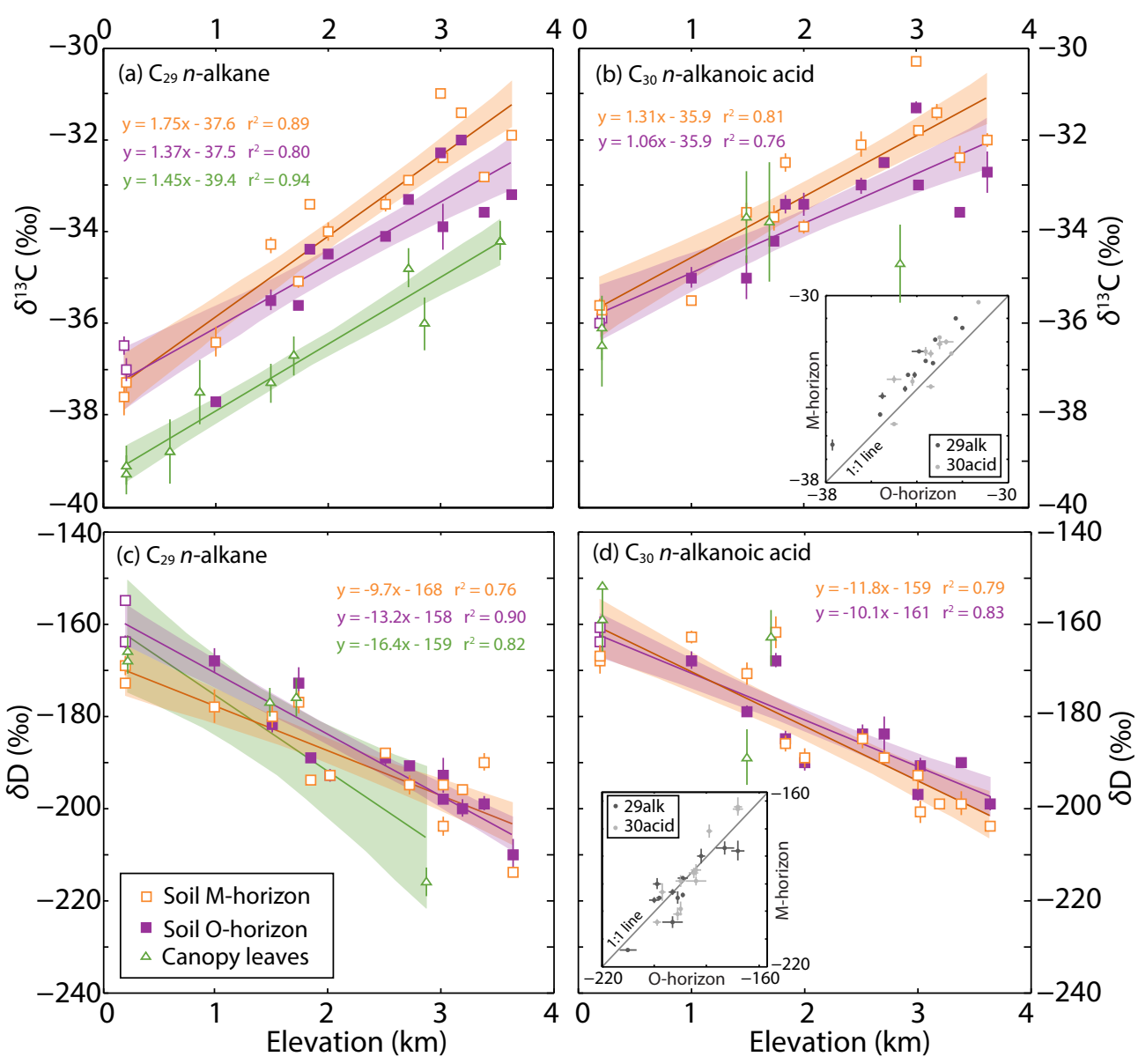
Figure 3

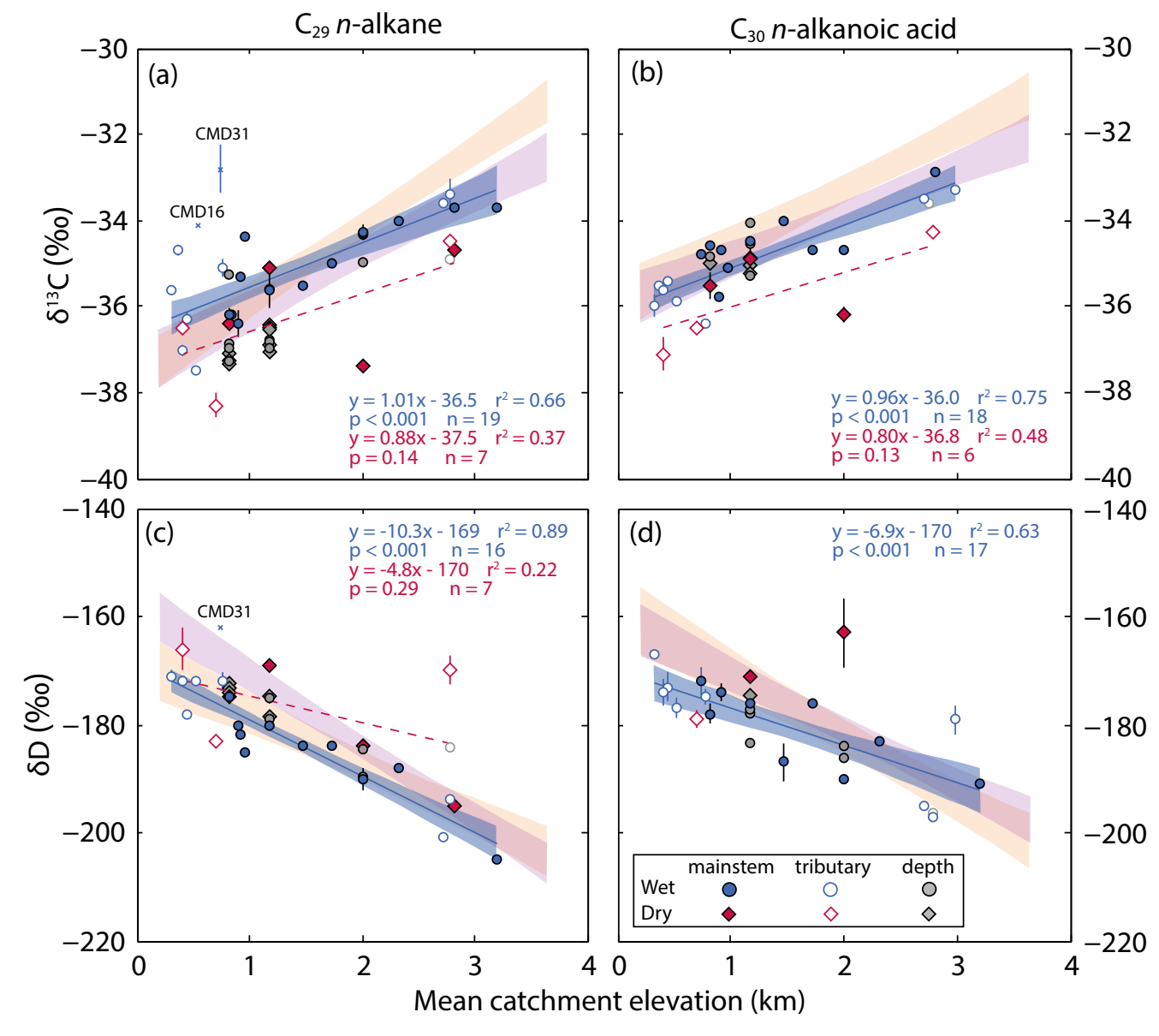


Figure 5

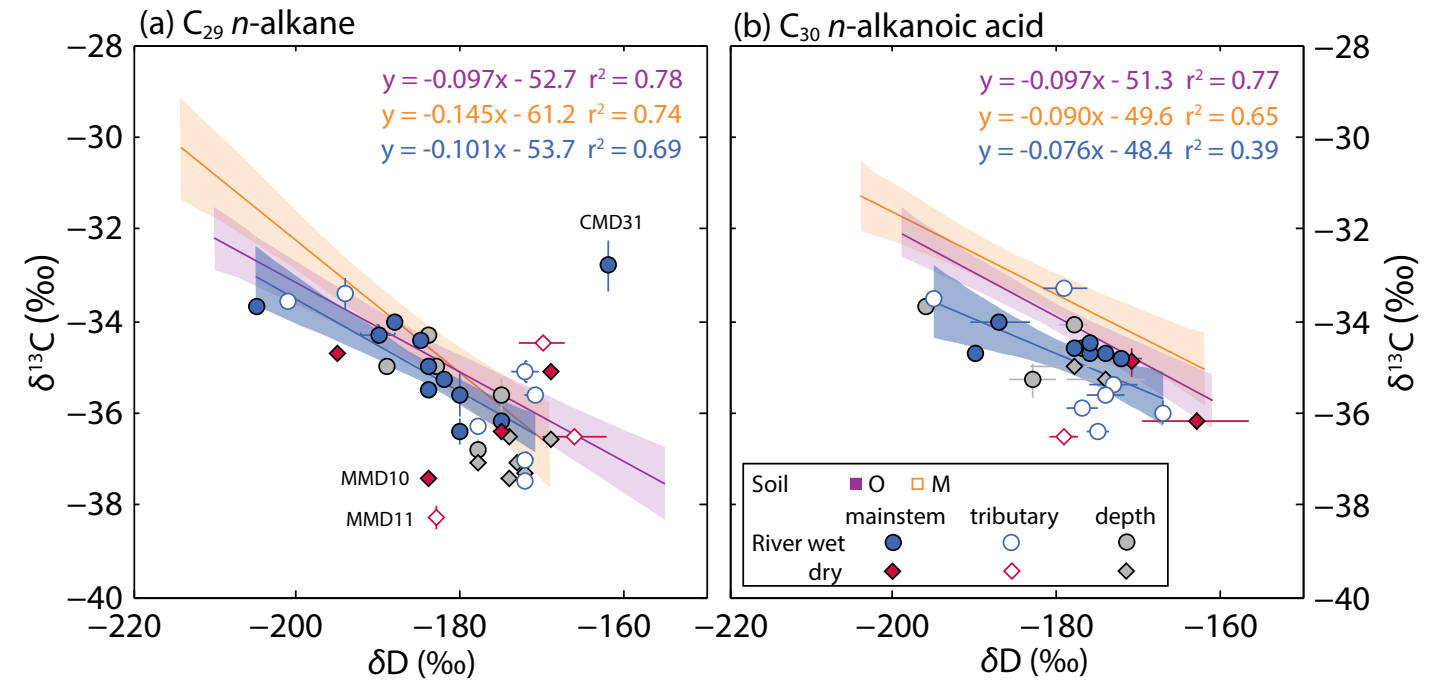




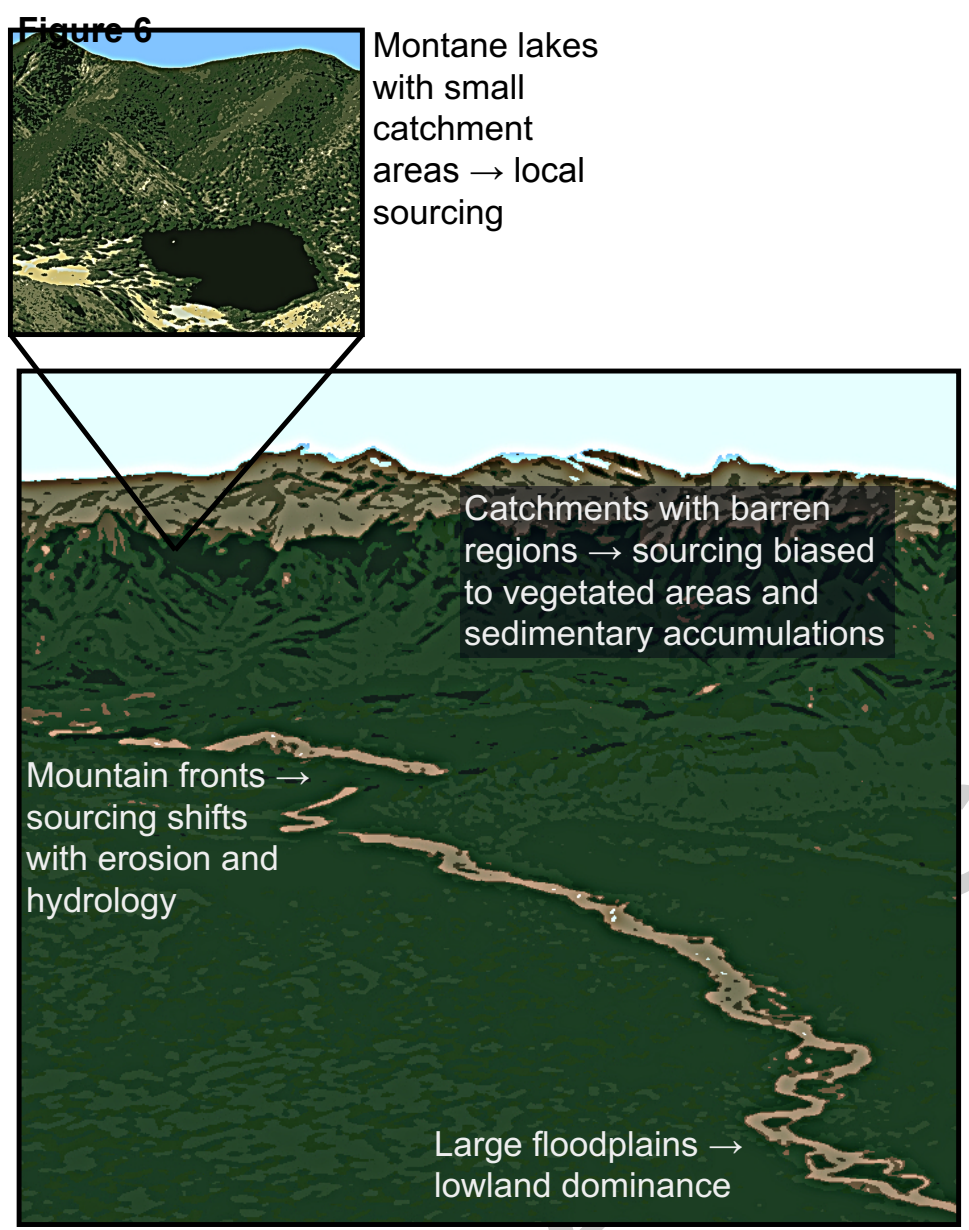


Figure 7

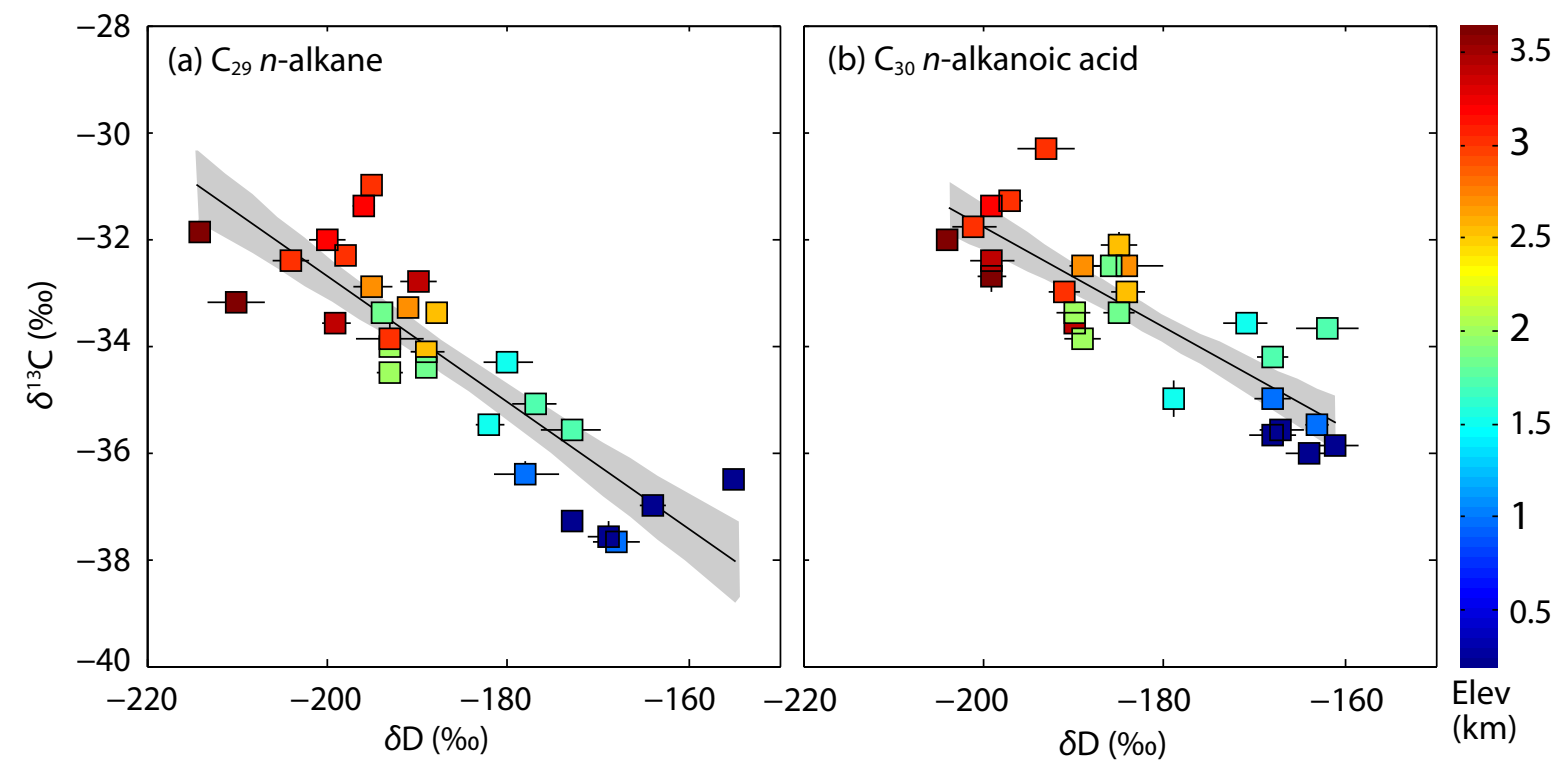

.5

2

.5

.

0.5 
Table 1. Predicting paleoaltimetry using a dual isotope plant wax approach in paleosols.

\begin{tabular}{llll}
\hline Proxy & $\begin{array}{l}\text { Elevation response } \\
\left(\% \circ \mathrm{km}^{-1}\right)\end{array}$ & $\begin{array}{l}\text { Predicted change after } \\
+2 \mathrm{~km} \text { uplift }(\%)\end{array}$ & $\begin{array}{l}\text { Uncertainty based on the } \\
\text { modern regression }(\mathrm{km})\end{array}$ \\
\hline$\delta^{3} \mathrm{C}_{29 \text { alk (soil M) }}$ & $+1.75 \pm 0.19$ & $+3.5 \pm 0.4$ & 0.2 \\
$\delta^{13} \mathrm{C} 30_{\text {acid (soil M) }}$ & $+1.31 \pm 0.21$ & $+1.6 \pm 0.4$ & 0.3 \\
$\delta \mathrm{D}_{29 \text { alk (soil M) }}$ & $-10 \pm 2$ & $-20 \pm 4$ & 0.3 \\
$\delta \mathrm{D}_{30 \text { acid (soil M) }}$ & $-12 \pm 2$ & $-24 \pm 4$ & 0.3 \\
\hline
\end{tabular}

*Additional uncertainties from aridity and plant type change may be constrained by dual isotope analyses, pollen information on plant communities, or other environmental evidence. These effects have the potential to confound estimates of elevation to the order of 2 or $20 \%$, for $\delta^{13} \mathrm{C}$ or $\delta \mathrm{D}$ respectively, equivalent to $2 \mathrm{~km}$. 